\title{
Measurement report: Spatial variability of northern Iberian rainfall stable isotope values - investigating atmospheric controls on daily and monthly timescales
}

\author{
Ana Moreno ${ }^{1}$, Miguel Iglesias ${ }^{2}$, Cesar Azorin-Molina ${ }^{3}$, Carlos Pérez-Mejías $^{4,1}$, Miguel Bartolomé ${ }^{5,6}$, \\ Carlos Sancho $^{5,+}$, Heather Stoll ${ }^{7}$, Isabel Cacho ${ }^{8}$, Jaime Frigola ${ }^{8}$, Cinta Osácar ${ }^{5}$, Arsenio Muñoz ${ }^{5}$, \\ Antonio Delgado-Huertas ${ }^{9}$, Ileana Bladé ${ }^{10}$, and Françoise Vimeux ${ }^{11,12}$ \\ ${ }^{1}$ Department of Geoenvironmental Processes and Global Change, Pyrenean Institute of Ecology - CSIC, \\ Avda. Montañana 1005, 50059 Zaragoza, Spain \\ ${ }^{2}$ Department of Geology, University of Oviedo, C/Arias de Velasco, s/no 33005 Oviedo, Spain \\ ${ }^{3}$ Centro de Investigaciones sobre Desertificación, Consejo Superior de Investigaciones Científicas (CIDE-CSIC), \\ 46113 Moncada, Valencia, Spain \\ ${ }^{4}$ Institute of Global Environmental Change, Xi' an Jiaotong University, Xi'an, 710049, China \\ ${ }^{5}$ Earth Sciences Department, University of Zaragoza, C/Pedro Cerbuna 12, 50009 Zaragoza, Spain \\ ${ }^{6}$ Departamento de Geología. Museo Nacional de Ciencias Naturales - CSIC, C/José Gutiérrez Abascal 2 , \\ 28006 Madrid, Spain \\ ${ }^{7}$ Geological Institute, NO G59, Department of Earth Sciences, Sonneggstrasse 5, ETH, 8092 Zurich, Switzerland \\ ${ }^{8}$ CRG Marine Geosciences, Department de Dinàmica de la Terra i de l'Oceà, Facultat de Ciències de la Terra, \\ Universitat de Barcelona, C/Martí i Franquès, s/no, 08028 Barcelona, Spain \\ ${ }^{9}$ Stable Isotope Biogeochemistry Laboratory, IACT-CSIC, Avda. de Las Palmeras no 4, 18100 Armilla (Granada), Spain \\ ${ }^{10}$ Group of Meteorology, Department of Applied Physics, Faculty of Physics, University of Barcelona, Martí i Franqués, \\ 1, 08028 Barcelona, Spain \\ ${ }^{11}$ HydroSciences Montpellier (HSM), UMR 5569 (UM, CNRS, IRD), 34095 Montpellier, France \\ ${ }^{12}$ Institut Pierre Simon Laplace (IPSL), Laboratoire des Sciences de Climat et du l'Environnement (LSCE), \\ UMR 8212 (CEA, CNRS, UVSQ), 91191 Gif-sur-Yvette, France \\ †deceased, February 2019
}

Correspondence: Cesar Azorin-Molina (cesar.azorin@uv.es)

Received: 17 August 2020 - Discussion started: 8 September 2020

Revised: 19 May 2021 - Accepted: 25 May 2021 - Published: 7 July 2021

\begin{abstract}
For the first time, this article presents a large dataset of precipitation isotopic measurements $\left(\delta^{18} \mathrm{O}_{\mathrm{p}}\right.$ and $\delta^{2} \mathrm{H}_{\mathrm{p}}$ ) sampled every day or $2 \mathrm{~d}$ from seven sites on a westto-east transect across northern Spain for 2010-2017. The main aim of this study is to (1) characterize the rainfall isotopic variability in northern Spain at daily and monthly timescales and (2) assess the principal factors influencing rainfall isotopic variability. The relative role of air temperature and rainfall in determining the stable isotope composition of precipitation changes along the west-to-east transect, with air temperature being highly correlated with $\delta^{18} \mathrm{O}_{\mathrm{p}}$
\end{abstract}

at daily and monthly timescales, while a few sites along the transect show a significant negative correlation with precipitation. The highest air temperature- $\delta^{18} \mathrm{O}_{\mathrm{p}}$ dependency is found for a station located in the Pyrenees. Frontal systems associated with North Atlantic cyclones are the dominant mechanism inducing precipitation in this region, particularly in winter. This study allows an exploration of the role of air mass source and trajectory in determining the isotopic composition of rainfall in northern Iberia by characterizing the moisture uptake for three of the seven stations. The importance of continental versus marine moisture sources is 
evident, with clear seasonal and spatial variations. In addition, the type of precipitation (convective versus frontal rainfall) plays a key role, with convective rainfall associated with higher $\delta^{18} \mathrm{O}_{\mathrm{p}}$ values. This comprehensive spatiotemporal approach to analyzing the rainfall isotopic composition represents another step forward towards developing a more detailed, mechanistic framework for interpreting stable isotopes in rainfall as a paleoclimate and hydrological tracer.

\section{Introduction}

The oxygen isotopic composition of rainfall $\left(\delta^{18} \mathrm{O}_{\mathrm{p}}\right)$ is often considered the dominant influence on the isotopic composition of terrestrial archives (ice cores, speleothems or authigenic lacustrine carbonates) used to reconstruct past climate (e.g., Leng, 2006). However, few paleoclimate reconstructions are supported by an in-depth understanding of the regional climatic controls on $\delta^{18} \mathrm{O}_{\mathrm{p}}$ (e.g., Treble et al., 2005). As a consequence, paleoclimate proxies are often interpreted without clear knowledge of the processes involved in modulating $\delta^{18} \mathrm{O}_{\mathrm{p}}$ in a particular region (López-Blanco et al., 2016; Moreno et al., 2017). It has long been established that $\delta^{18} \mathrm{O}_{\mathrm{p}}$ is an integrated product of air mass history modulated by specific prevailing meteorological conditions, in particular air temperature and amount of precipitation (Craig, 1961; Dansgaard, 1964). This implies that several dominant factors may control $\delta^{18} \mathrm{O}_{\mathrm{p}}$ variability depending on the site location, i.e., latitude, continentality, elevation, seasonal distribution, local air temperature, and the amount and source of precipitation (Rozanski et al., 1993). A detailed study of current $\delta^{18} \mathrm{O}_{\mathrm{p}}$ values and their variability in a given region is essential to reconstructing past climate changes using $\delta^{18} \mathrm{O}$ in regional climate archives (Lachniet, 2009).

Long rainfall isotopic time series allow for comparison of the $\delta^{18} \mathrm{O}_{\mathrm{p}}$ signal with meteorological variables and calibration of proxy records. Unfortunately, such long-term observational studies are scarce, and thus only a few outstanding examples of studies examining factors controlling $\delta^{18} \mathrm{O}_{\mathrm{p}}$ are available for continental Europe (Field, 2010; Genty et al., 2014; Tyler et al., 2016). Yet, results obtained for European regions mostly under the influence of rainfall with Atlantic origin (e.g., Baldini et al., 2010) cannot be directly applied to the Iberian Peninsula (IP), where three major weather precipitation regimes coexist (Millán et al., 2005) and where potential for paleoclimate reconstructions exists via speleothemderived proxies. Previous studies have shown that the spatial distribution of $\delta^{18} \mathrm{O}_{\mathrm{p}}$ and $\delta^{2} \mathrm{H}_{\mathrm{p}}$ on monthly timescales in Spain can be approached by a simple multiple regression model based on only two geographic factors: latitude and elevation (Díaz-Tejeiro et al., 2007, 2013). However, this model does not reproduce the observed distribution of stable isotope precipitation composition with detailed spatial resolution. The well-known complex topography and varied weather regimes of the Iberian Peninsula (AEMET and Instituto de Meteorologia de Portugal, 2011; Martin-Vide and Olcina-Cantos, 2001) require more targeted studies that take into account the high spatial variability of $\delta^{18} \mathrm{O}_{\mathrm{p}}$ in Iberia and the multiple (and sometimes overlapping) processes determining its temporal variation.

A major advance in understanding the controls on $\delta^{18} \mathrm{O}_{\mathrm{p}}$ has been the proliferation of studies using daily-scale monitoring to address the mechanisms behind isotopic signatures at daily timescales (Baldini et al., 2010; Fischer and Baldini, 2011), which incorporate the complexity associated with the different types of rainfall (e.g., frontal or convective system) (Aggarwal et al., 2016). Regrettably, the scarcity of Global Network of Isotopes in Precipitation (hereafter GNIP) sites in Iberia, particularly those using data at daily timescales, prevents a broader regional study of climate controls on $\delta^{18} \mathrm{O}_{\mathrm{p}}$ values. In the IP, only one study has analyzed $\delta^{18} \mathrm{O}_{\mathrm{p}}$ variability on a daily basis over a short 3-year period (20002002) (Araguás-Araguás and Diaz Teijeiro, 2005), and more recently a 3-year monitoring survey focused on the Iberian Range (Molinos Cave, Teruel, NE Spain) (Moreno et al., 2014). That study revealed the importance of the source effect on $\delta^{18} \mathrm{O}_{\mathrm{p}}$ values due to the alternating influence of two air masses with different origins and different isotopic ranges: Atlantic fronts, which are associated with more negative $\delta^{18} \mathrm{O}_{\mathrm{p}}$ values (from the west), and Mediterranean convective storms with more positive values (eastern sources) (Moreno et al., 2014). Additionally, another recent study based on back trajectories emphasized the role of recycled moisture uptake within the IP in the final values of $\delta^{18} \mathrm{O}_{\mathrm{p}}$ in central Spain (Eagle Cave) (Krklec and Domínguez-Villar, 2014). Besides those studies based on $\delta^{18} \mathrm{O}_{\mathrm{p}}$, another recent work focused on trace elements in precipitation at two Pyrenean sites reveals the importance of seasonality in the role played by continental vs. marine sources of moisture (Suess et al., 2019). In addition, to date, the majority of empirical studies of meteorological controls over $\delta^{18} \mathrm{O}_{\mathrm{p}}$ are based on event, daily or monthly time series from individual locations (Moreno et al., 2014; Smith et al., 2016). The scarce studies dealing with multiple sampling locations span areas under the influence of the same climatic regime (Baldini et al., 2010; Jeelani et al., 2018). This approach raises concerns about the spatial representativeness of the resulting statistical models and the mechanisms behind the identified relationships in areas as complex as the IP.

In this paper we present a comprehensive analysis of daily and monthly patterns of $\delta^{18} \mathrm{O}_{P}$ from multiple stations across northern IP all the way to the Balearic Islands, following an $850 \mathrm{~km}$ long west-to-east transect that extends from an area dominated by a typical Atlantic climate to one dominated by a Mediterranean climate. The overall aim is to characterize the dominant factors modulating $\delta^{18} \mathrm{O}_{\mathrm{p}}$ variations in time (daily and monthly) and space in order to determine the causes of regional precipitation isotope variations. The role of geographic factors (continental and elevation effects) and 
atmospheric processes (moisture origin and type of rainfall) is evaluated. Additionally, this study will serve to improve the interpretation of oxygen isotope paleorecords from the northern IP that depend on $\delta^{18} \mathrm{O}_{\mathrm{p}}$ (Bartolomé et al., 2015; Domínguez-Villar et al., 2017; López-Blanco et al., 2016; Pérez-Mejías et al., 2019; Sancho et al., 2018, 2015).

\section{Weather regime, climate and site description}

Our study compares, for the first time, rainfall isotopic values and meteorological variables (air temperature, precipitation, moisture source and type of rainfall) at seven sites in northern Iberia and the Balearic Islands, covering an $850 \mathrm{~km}$ long west-to-east transect from an area under a typical Atlantic climate (Oviedo and El Pindal) to a fully Mediterranean climate (Mallorca and Barcelona). The west-to-east transect is completed with three additional sites in a transitional zone: two from the Iberian Range (Molinos and Ortigosa de Cameros) and one from the Pyrenees (Borrastre) (Fig. 1a). At those seven locations, rainfall was sampled on a daily basis except at El Pindal where it was collected every $48 \mathrm{~h}$ (Table 1). The Borrastre record is, to our knowledge, the most comprehensive dataset of daily $\delta^{18} \mathrm{O}_{\mathrm{p}}$ for Spain in terms of both time span covered (2011-2016) and number of samples (380 d) (Table S1).

In northwestern and north-central Iberia, precipitation is mainly controlled by the presence of westerly winds and the passage of Atlantic fronts, especially during NovemberApril (Martín-Vide and Olcina Cantos, 2001; Rüdisühli et al., 2020). During the rest of the year, the subtropical Azores high-pressure system shifts northward, which blocks the westerly circulation and moisture inflow from Atlantic sources (Archer and Caldeira, 2008), thus favoring stable atmospheric conditions and reducing precipitation. This wet winter-dry summer regime is quite different from that in the northeastern Mediterranean region of Iberia, where winters are generally dry, whereas in the warm season (from late spring to early autumn) precipitation is more abundant and dominated by convective storms and also fronts that approach the IP from the east (backdoor cold fronts) (Millán et al., 2005). This mesoscale circulation is primarily associated with frequent and persistent sea breezes (Azorin-Molina et al., 2011), which bring warm and moist air masses from the Mediterranean Sea inland (Azorin-Molina et al., 2009). During the summer season, this is typically the only source of precipitation in the northeastern IP, bringing an average of 100-125 mm yearly (Millán et al., 2005). Backdoor cold fronts from the Mediterranean Sea are sporadic events occurring mainly in autumn (and to a lesser extent in winterspring) but that can cause heavy precipitation and flooding (Llasat et al., 2007). Figure 1b summarizes the three major precipitation regimes defined by Millán et al. (2005): (i) Atlantic frontal systems (westerly winds), (ii) convective-

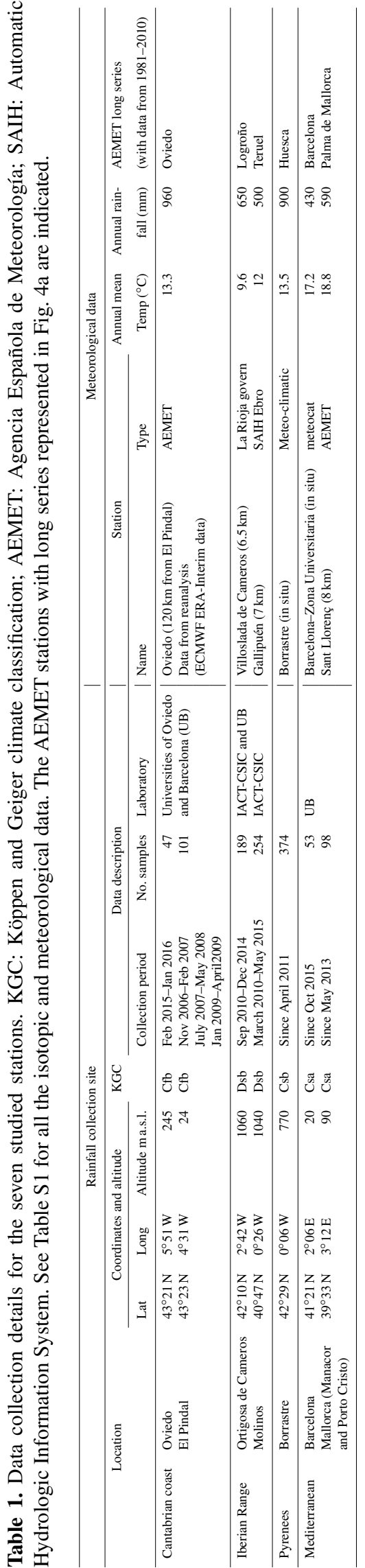

Atmos. Chem. Phys., 21, 10159-10177, 2021 


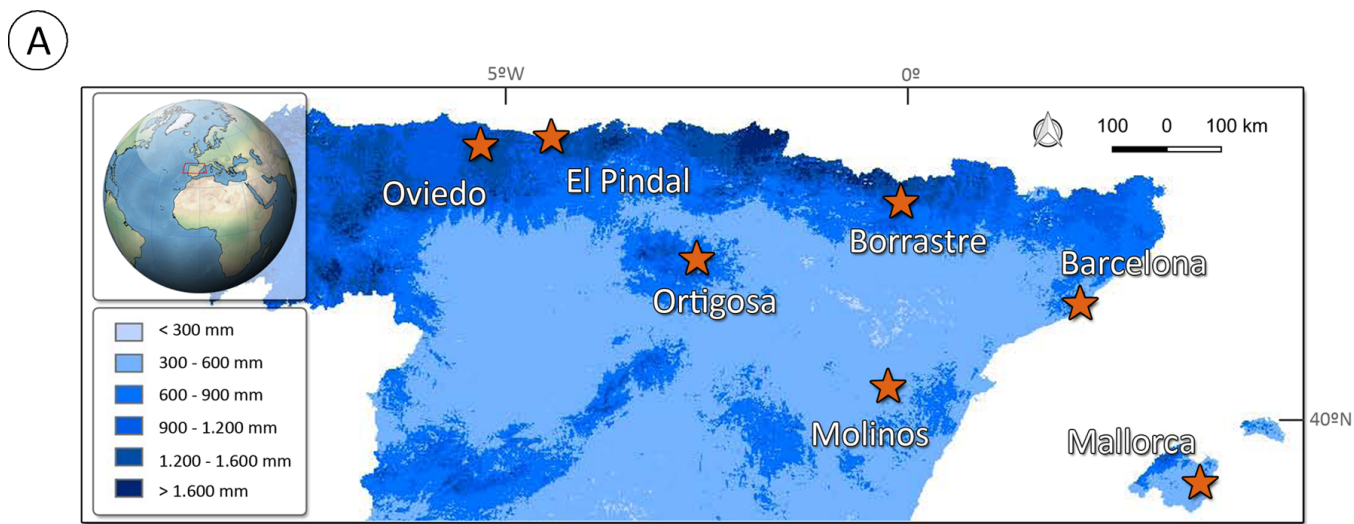

(B)
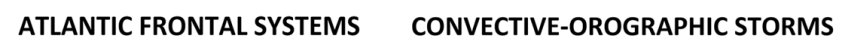

BACKDOOR COLD FRONTS MEDITERRANEAN
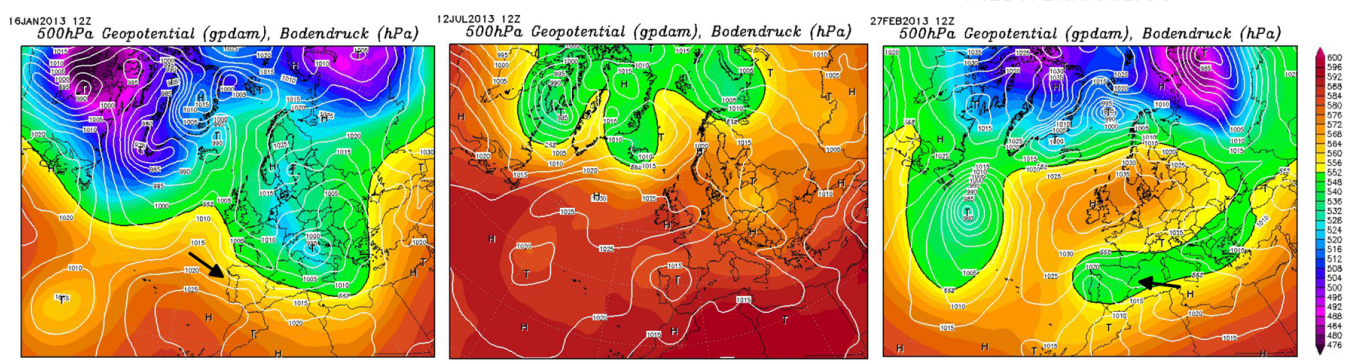

Figure 1. (a) Location of the studied stations in northern Spain where rainfall was collected. Map source: average annual precipitation (mm) for 1980-2005 provided by the Spanish Ministry of Agriculture and Fisheries, Food and Environment (MAPAMA). (b) Weather maps showing the three precipitation regimes of the IP defined by Millán et al. (2005): (i) Atlantic frontal systems, (ii) convective-orographic storms and (iii) backdoor cold fronts from the Mediterranean Sea. In the maps, the sea level pressure and the $500 \mathrm{hPa}$ geopotential height (gpdam in German) are indicated by the different colors; the scale represents the height - from 4600 to $6000 \mathrm{~m}-$ at which the pressure of $500 \mathrm{hPa}$ is reached. White lines are the isobars (Bodendruck in German). Source: CFS Reanalysis (CFSR) and Wetterzentrale.

orographic storms and (iii) backdoor cold fronts from the Mediterranean Sea (easterly winds).

Below, the seven studied stations are grouped into four regions and described in terms of their climatology.

The Cantabrian coast. The sites of El Pindal and Oviedo on the Cantabrian coast (Fig. 1a) are characterized by a typical oceanic climate with mild summers and winters (Cfb, following Köppen and Geiger - KGC - classification) due to the proximity to the coast. Rainfall occurs along the whole year with a minimum in summer and is associated with Atlantic frontal systems (westerly winds).

The Iberian Range. Ortigosa de Cameros is located in the Encinedo Mountain area in the westernmost sector of the Cameros Range (Iberian Range, Fig. 1a) and is dominated by a continental Mediterranean climate (Dsb, following KGC classification). Rainfall occurs mostly in autumn and spring, with some convective-orographic storms in summer. The Molinos site is also located in the Iberian Range and at a similar elevation but further east in the Maestrazgo basin. It is characterized by a similar climate (Dsb in KGC classification), with a highly pronounced seasonality; precipitation occurs mainly in spring and autumn.
The Pyrenees. Borrastre village is located in the central Pyrenees (Fig. 1a) and has a transitional climate from Mediterranean to oceanic (Csb in KGC classification), with precipitation occurring mainly in spring and to a lesser extent in autumn, exhibiting a mix of the three Atlantic, Mediterranean and convective precipitation regimes.

The Mediterranean. The typical Mediterranean climate (Csa in KGC classification) is represented by the Manacor and Porto Cristo localities in Mallorca and by Barcelona (Fig. 1a). Precipitation is mostly distributed from October to April, typically associated with backdoor cold fronts from the Mediterranean Sea (easterly winds) as the influence of Atlantic precipitation is weak over this area.

\section{Analytical and statistical methods}

\subsection{Sampling}

Rainwater was collected using a similar procedure as that recommended by the International Atomic Energy Agency (IAEA) for daily sampling (http://www-naweb.iaea.org/ napc/ih/IHS_resources_gnip.html, last access: 20 June 2021) for six of the seven stations (Oviedo, Ortigosa de Cameros, 
Molinos, Borrastre, Mallorca and Barcelona). Precipitation events greater than or equal to $1 \mathrm{~mm}$ were sampled manually from the water accumulated in the rain gauge using a syringe. The collected water was then homogenized and filtered at the time of sampling; later a $5 \mathrm{~mL}$ aliquot was stored in polypropylene tubes sealed with a screw cap without air inside and kept cold in a refrigerator until analyzed. Rainfall samples were collected at the end of each precipitation event, immediately afterwards whenever possible or after a few hours, with the total event precipitation being homogenized. At the El Pindal site the procedure was different: rainfall was collected every $48 \mathrm{~h}$ for several months (November 2006 to April 2009, a total of 101 samples) using an automated self-built revolver-type sampler that contained $241 \mathrm{~L}$ Nalgene bottles, thus avoiding any mixing of subsequent samples (see Fischer et al., 2019). A film of paraffin oil was used to prevent evaporation. It was located on the roof of the San Emeterio lighthouse $<10 \mathrm{~m}$ from the modern sea cliff (Table 1).

The observation staff in charge of each location collected a sample directly following every rainfall event, except in El Pindal, which has an automatic system, and in Mallorca where several events were missed during the first 2 years of the collection period, preventing the calculation of monthly averages for some intervals (monthly and annual averages and standard deviations in Table 2). Thus, 47 rainfall samples were collected from Oviedo manually in 2015. In Ortigosa de Cameros, rainfall was manually collected daily between September 2010 and December 2014 by the staff (guides) of the La Viña and La Paz show caves, with an interruption from December 2012-January 2014 (total of 193 samples). In Molinos, rainfall was manually collected by the staff of the Grutas de Cristal cave every day for just over 5 years (March 2010-May 2015, 268 samples). The first 3 years of rainfall data from that survey were previously published (Moreno et al., 2014; Pérez-Mejías et al., 2018). In Borrastre, rainfall was manually collected daily using a Hellman rain gauge from April 2011 to May 2016 (380 events). In Barcelona, rainfall samples were manually obtained from the weather station on the roof of the School of Physics of the University of Barcelona using a standard rain gauge (53 samples). In addition, 98 rainfall events were collected in Mallorca; 7 were replicated at two different localities (Manacor and Porto Cristo), obtaining similar $\delta^{18} \mathrm{O}_{\mathrm{p}}$ results. For those seven events, a weighted average value using the two localities was calculated (see Table S1).

\subsection{Analytical methods}

The isotopic composition of oxygen and hydrogen in rainfall samples is expressed as $\delta^{18} \mathrm{O}$ and $\delta^{2} \mathrm{H}$ in per mill (\%o) relative to Vienna Standard Mean Ocean Water (VSMOW). Molinos, Borrastre and most of the Ortigosa de Cameros samples (143 samples) were analyzed using a Finningan Delta Plus XL mass spectrometer at the IACT-CSIC in Granada. Wa- ter samples were equilibrated with $\mathrm{CO}_{2}$ for the analysis of $\delta^{18} \mathrm{O}$ values (Epstein and Mayeda, 1953), while the hydrogen isotopic ratios were measured on $\mathrm{H}_{2}$ produced by the reaction of $10 \mu \mathrm{L}$ of water with metallic zinc at $500^{\circ} \mathrm{C}$, following the analytical method of Coleman et al. (1982). The analytical error for $\delta^{18} \mathrm{O}$ and $\delta^{2} \mathrm{H}$ was $\pm 0.1 \%$ and $\pm 1 \%$, respectively. The Mallorca and Barcelona samples and the remaining samples from Ortigosa de Cameros (50 samples) were analyzed at the Scientific and Technological Centre at the University of Barcelona, $\delta^{2} \mathrm{H}$ via a thermal conversion elemental analyzer (TCEA) for pyrolysis coupled to a Thermo Delta Plus XP mass spectrometer, and $\delta^{18} \mathrm{O}$ with a MAT 253 Thermo Fisher spectrometer coupled with a gas bench. The analytical error for $\delta^{18} \mathrm{O}$ and $\delta^{2} \mathrm{H}$ was $\pm 0.2 \%$ and $\pm 1.5 \%$, respectively. El Pindal samples were measured at three different laboratories (see Stoll et al., 2015, for more details). Rainfall collected from November 2006 through the end of February 2007 was analyzed at the University of Barcelona using the procedure described above. Rainfall collected from June 2007 to May 2008 was analyzed in the Marine Biological Laboratories of the University of Oviedo using equilibration with $\mathrm{CO}_{2}$ on a $\mathrm{GV}$ Multiflow-Bio unit coupled to a GV ISOPRIME CF mass spectrometer. Rainfall collected from June 2008 to April 2009 and samples from 2015 were analyzed using equilibration with $\mathrm{CO}_{2}$ on a Gas Prep unit coupled to a $\mathrm{Nu}$ Instruments Horizon mass spectrometer at the University of Oviedo. Uncertainties are $\pm 0.1 \%$ ( $1 \mathrm{~s}$ ) for $\delta^{18} \mathrm{O}$ and $\pm 1 \%$.for $\delta^{2} \mathrm{H}$ based on replicate analyses. Unfortunately, no comparison was made between the different involved laboratories and thus the study does not account for possible offsets between them.

Additionally, 18 samples of potentially evaporated water with abnormally high values of $\delta^{18} \mathrm{O}_{\mathrm{p}}$ - and that occurred in summer months when maximum daily air temperatures exceeded $30^{\circ} \mathrm{C}$ - were classified as outliers and removed from the database. These 18 samples (Table S1) were from Ortigosa de Cameros (4 samples), Borrastre (6 samples) and Molinos (8 samples). Partial evaporation of falling rain droplets is an alternative interpretation for the high $\delta^{18} \mathrm{O}_{\mathrm{p}}$ values of these samples.

\subsection{Meteorological data}

Air temperature and precipitation (on daily and monthly timescales) were obtained from the closest meteorological stations over the sampling periods, as indicated in Table 1, to investigate the statistical relationship with isotopic values. For Oviedo, meteorological data are obtained from the Oviedo AEMET station. For El Pindal $(120 \mathrm{~km}$ from Oviedo; $70 \mathrm{~km}$ from Santander), since there were no good data from nearby stations, we decided to use the ERAInterim reanalysis from the European Centre for MediumRange Weather Forecasts (ECMWF), which provides gridded weather data (Berrisford et al., 2009; Dee et al., 2011). For the Ortigosa site, meteorological data were obtained 
Table 2. Mean values of $\delta^{18} \mathrm{O}_{\mathrm{p}}$ data for every station in the study transect at a monthly and annual scale. Only months and years with all events collected are averaged. Note that the number of months or years averaged (number between brackets after the $\delta^{18} \mathrm{O}_{\mathrm{p}}$ values) is not the same for all the stations, and neither is the time period considered (check Table 1 for the sampling period at every station). For the complete monthly dataset with all the monthly values indicated, please see Table S2.

\begin{tabular}{|c|c|c|c|c|c|c|c|}
\hline \multirow[t]{2}{*}{$\delta^{18} \mathrm{O}_{\mathrm{p}}(\% o)$} & \multicolumn{2}{|c|}{ Cantabrian coast } & \multicolumn{2}{|c|}{ Iberian Range } & \multirow{2}{*}{$\begin{array}{l}\text { Pyrenees } \\
\text { Borrastre }\end{array}$} & \multicolumn{2}{|c|}{ Mediterranean } \\
\hline & Oviedo & El Pindal & Ortigosa de Cameros & Molinos & & Barcelona & Mallorca \\
\hline January & & $-7.46(3)$ & $-12.29(2)$ & $-10.12(4)$ & $-8.64(4)$ & $-5.15(1)$ & $-8.91(4)$ \\
\hline February & & $-5.49(2)$ & $-7.28(3)$ & $-9.71(5)$ & $-11.25(4)$ & $-6.71(2)$ & $-4.57(4)$ \\
\hline March & $-6.29(1)$ & $-5.19(2)$ & $-7.74(3)$ & $-10.25(6)$ & $-9.49(4)$ & $-8.00(2)$ & $-7.15(3)$ \\
\hline April & $-5.12(1)$ & $-4.27(2)$ & $-6.25(4)$ & $-7.68(6)$ & $-6.35(4)$ & $-7.38(2)$ & $-4.86(3)$ \\
\hline May & & $-5.25(1)$ & $-3.66(3)$ & $-6.13(5)$ & $-5.19(6)$ & $-2.21(2)$ & $-3.36(3)$ \\
\hline June & $-3.73(1)$ & & $-5.21(4)$ & $-5.12(4)$ & $-4.32(5)$ & $-8.01(1)$ & $-3.06(2)$ \\
\hline July & $-7.50(1)$ & $-2.04(1)$ & $-6.39(4)$ & $-2.22(4)$ & $-4.44(5)$ & $-1.64(1)$ & $-1.13(1)$ \\
\hline August & $-4.80(1)$ & $-3.94(1)$ & $-3.64(4)$ & $-5.00(4)$ & $-4.65(5)$ & & $-3.15(3)$ \\
\hline September & $-5.83(1)$ & $-3.17(1)$ & $-7.09(3)$ & $-5.93(3)$ & $-5.83(5)$ & $-6.13(1)$ & $-4.14(5)$ \\
\hline October & $-5.47(1)$ & $-4.12(1)$ & $-6.17(4)$ & $-7.18(3)$ & $-6.46(5)$ & $-5.53(1)$ & $-6.38(4)$ \\
\hline November & $-5.87(1)$ & $-4.31(1)$ & $-9.40(4)$ & $-11.26(4)$ & $-7.24(5)$ & $-6.95(2)$ & $-6.34(4)$ \\
\hline December & $-7.16(1)$ & $-5.23(2)$ & $-7.91(3)$ & $-10.41(3)$ & $-8.00(4)$ & $-7.27(1)$ & $-5.28(4)$ \\
\hline Annual & & & $-7.09(1)$ & $-7.18(2)$ & $-6.37(3)$ & & \\
\hline
\end{tabular}

from the Villoslada de Cameros meteorological station (http: //www.larioja.org/emergencias-112/es/meteorologia, last access: 20 June 2021), $6.5 \mathrm{~km}$ away from the rainfall collection site. The Borrastre sampling site has its own meteorological station (http://www.climaynievepirineos.com/estaciones/ borrastre.htm, last access: 5 July 2021) (Table 1), but for the first 22 events data were obtained from ERA-Interim since the station was not yet operative. Finally, for Mallorca we used data from the Sant Llorenç station $(8 \mathrm{~km})$, while Barcelona meteorological data are obtained from the Zona Universitaria station (http://www.meteo4u.com, last access: 20 June 2021).

\subsection{Statistical analyses}

Prior to conducting correlation analysis at daily timescales, we removed the seasonal cycle of the variables by subtracting their monthly averages to avoid sympathetic seasonal correlations (e.g., Kawale et al., 2011; Rozanski et al., 1993) (Table $3 \mathrm{a}$ ). To establish correlations on the monthly scale with meteorological variables (Table $3 \mathrm{~b}$ ), $\delta^{18} \mathrm{O}_{\mathrm{p}}$ monthly averages weighted by the amount of precipitation were calculated using the following formula:

$$
\begin{aligned}
& \delta^{18} \mathrm{O}_{\text {monthly }}=\left(\left(Q_{1} \times \delta^{18} \mathrm{O}_{1}\right)+\left(Q_{2} \times \delta^{18} \mathrm{O}_{2}\right)\right. \\
&\left.\ldots\left(Q_{i} \times \delta^{18} \mathrm{O}_{i}\right)\right) /\left(Q_{1}+Q_{2}+\ldots Q_{i}\right)
\end{aligned}
$$

where $Q$ is the rainfall quantity for day $i$ (in $\mathrm{mm}$ ). Daily values were not averaged since there was only one rainfall sample per day due to the homogenization of all event samples from that day. Spearman's rank correlation analysis, a nonparametric measure as an alternative to Pearson correlation analysis, was preferred to account for nonlinear rela- tionships, with $r$ indicating the correlation coefficient (PAST software; Hammer et al, 2001). The analyses were conducted on daily (Table 3a) and monthly (Table 3b) timescales. The Bonferroni test was applied to prevent data from spuriously appearing as statistically significant by making an adjustment during comparison testing. Additionally, to integrate both air temperature and rainfall amount effects, a multiple regression model for $\delta^{18} \mathrm{O}$ was carried out using PAST software for every studied site (Table $3 \mathrm{c}$ ).

\subsection{Backward-trajectory and moisture uptake analysis}

Backward-trajectory analysis was performed using the HYbrid Single-Particle Lagrangian Integrated Trajectory (HYSPLIT) model (version 4.8) (Draxler and Rolph, 2010) following a similar methodology as in Baldini et al. (2010) over a $24 \mathrm{~h}$ lifetime ( $120 \mathrm{~h}$ trajectories were also calculated; Fig. S1) for three of the seven stations: Oviedo, Borrastre and Mallorca. The Global Data Assimilation System (GDAS) has been used in HYSPLIT simulations with $0.5^{\circ} \times 0.5^{\circ}$ spatial resolution. Thus, to facilitate the statistical comparison of mean trajectory paths and moisture uptake regions with the oxygen isotope signature of sampled rain events, the vector angle between every site (Oviedo-Borrastre-Mallorca) and each hourly position along $24 \mathrm{~h}$ back trajectories (at 700 and $850 \mathrm{hPa}$ ) for each event was estimated following the methodology presented in Baldini et al. (2010). Once all the vectors that represent the mean trajectory of the air mass transport associated with precipitation were produced for each sampled event, they were averaged and presented in a compass rose using $10^{\circ}$ intervals, together with $\delta^{18} \mathrm{O}_{\mathrm{p}}$ values and rainfall amount for each daily sample $(\mathrm{mm})$ provided by weather stations close to each analyzed location. To explore the moisture 
Table 3. Spearman's rank correlation coefficients between $\delta^{18} \mathrm{O}_{\mathrm{p}}$ and air temperature as well as precipitation amount for every sampling station at a daily scale (a) and monthly scale (b) using deseasonalized data (removing the seasonal component by subtracting their monthly averages). Significant correlations with $p$ value $<0.05$ after application of the Bonferroni test are in italics. Note that the relatively small size of Oviedo and Barcelona rain events likely precludes statistically significant correlations. (c) The multiple regression coefficient $(r)$ and $p$ value for every site are included, indicating the coefficient and the standard error for the constant, precipitation and air temperature variables. As an example, the equation for Molinos should be read as follows: $\delta^{18} \mathrm{O}_{\mathrm{p}}=-0.05( \pm 0.019) A+0.40( \pm 0.05) T+0.43$, with $A$ as the amount of precipitation, $T$ as air temperature and 0.43 as a constant value.

\begin{tabular}{|c|c|c|c|c|c|c|c|c|}
\hline & & Oviedo & El Pindal & $\begin{array}{r}\text { Ortigosa } \\
\text { de Cameros }\end{array}$ & Molinos & Borrastre & Barcelona & Mallorca \\
\hline (a) Daily correlations & & $n=39$ & $n=109$ & $n=189$ & $n=248$ & $n=352$ & $n=53$ & $n=98$ \\
\hline \multirow[t]{2}{*}{$\delta^{18} \mathrm{O}_{\mathrm{p}}$-temperature } & $r_{\mathrm{s}}$ & 0.23 & 0.34 & 0.25 & 0.41 & 0.31 & 0.24 & 0.35 \\
\hline & $p$ value & 0.328 & 0.0012 & 0.001 & $2.00 \times 10^{-11}$ & $1.17 \times 10^{-09}$ & 0.21 & 0.0013 \\
\hline \multirow[t]{2}{*}{$\delta^{18} \mathrm{O}_{\mathrm{p}}$-precipitation amount } & $r_{\mathrm{s}}$ & -0.22 & -0.06 & -0.32 & -0.19 & -0.11 & -0.35 & -0.28 \\
\hline & $p$ value & 0.368 & 1 & $1.05 \times 10^{-05}$ & 0.005 & 0.119 & 0.029 & 0.013 \\
\hline (b) Monthly correlations & & $n=9$ & $n=17$ & $n=41$ & $n=51$ & $n=49$ & $n=16$ & $n=40$ \\
\hline \multirow{2}{*}{$\delta^{18} \mathrm{O}_{\mathrm{p}}$-temperature } & $r_{\mathrm{s}}$ & 0.3 & 0.33 & 0.46 & 0.76 & 0.61 & 0.39 & 0.41 \\
\hline & $p$ value & 1 & 1 & 0.013 & $3.36 \times 10^{-10}$ & $1.44 \times 10^{-05}$ & 0.804 & 0.05 \\
\hline \multirow{2}{*}{$\delta^{18} \mathrm{O}_{\mathrm{p}}$-precipitation amount } & $r_{\mathrm{s}}$ & 0.066 & -0.44 & -0.34 & -0.4 & -0.11 & -0.30 & -0.12 \\
\hline & $p$ value & 0.843 & 0.4 & 0.176 & 0.018 & 1 & 1 & 0.436 \\
\hline \multirow[t]{2}{*}{ (c) Multiple regression (with daily data) } & $r$ & 0.30 & 0.40 & 0.40 & 0.43 & 0.30 & 0.32 & 0.41 \\
\hline & $p$ value & 0.118 & 0.0001 & $3.36 \times 10^{-08}$ & $4.68 \times 10^{-13}$ & $8.13 \times 10^{-09}$ & 0.004 & 0.008 \\
\hline \multirow[t]{2}{*}{ Constant } & Coeff & 0.14 & 0.32 & -1.6 & 0.43 & $-2.83 \times 10^{-11}$ & -0.49 & 0.23 \\
\hline & SE & 0.43 & 0.24 & 0.22 & 0.18 & 0.16 & 0.38 & 0.26 \\
\hline \multirow[t]{2}{*}{ Precipitation } & Coeff & -0.015 & -0.013 & -0.11 & -0.05 & -0.018 & -0.05 & -0.02 \\
\hline & SE & 0.05 & 0.04 & 0.02 & 0.019 & 0.014 & 0.02 & 0.017 \\
\hline \multirow[t]{2}{*}{ Temperature } & Coeff & 0.21 & 0.25 & 0.25 & 0.40 & 0.40 & 0.37 & 0.31 \\
\hline & $\mathrm{SE}$ & 0.11 & 0.05 & 0.06 & 0.05 & 0.06 & 0.19 & 0.11 \\
\hline
\end{tabular}

uptake along the backwards trajectories, we have performed a new analysis in all events ( $850 \mathrm{hPa}$ trajectories) using Baldini's method (Baldini et al., 2010) in a more restrictive way (see also Iglesias González, 2019) to identify the locations where moisture uptake processes took place during the $48 \mathrm{~h}$ before the rainfall samples were collected. Taking into account that the Iberian Peninsula is surrounded by ocean, together with the fact that most of the analyzed rainfall events were produced by frontal systems and convection events (see synoptic analysis), only $850 \mathrm{hPa}$ air mass moisture uptake events have been considered relevant to our new analysis. In addition, while Baldini et al. (2010) considered moisture uptake processes with an increase of $0.1 \mathrm{~g}$ of $\mathrm{H}_{2} \mathrm{O}_{v}$ per $\mathrm{kg}_{\text {air }}$ in $1 \mathrm{~h}$ to be significant, in our analysis we only took into account events in which moisture uptake was higher than $0.25 \mathrm{~g}$ of $\mathrm{H}_{2} \mathrm{O}_{v}$ per $\mathrm{kg}_{\text {air }}$; therefore, if there is any influence on the rainfall isotopic signal, it would be easier to identify than in previous studies. With this restricted method and considering all the events examined, more than 3000 moisture uptake events have been identified. These events were analyzed considering seasonal variability and the different locations where the rainfall samples were collected (Oviedo, Borrastre, Mallorca).

\subsection{Precipitation types}

Lastly, to better explore the role of the type of precipitation in controlling the isotopic composition of rainfall across northern Iberia, we applied a disaggregation procedure of the precipitation series on the basis of their meteorological origin following the same subjective criteria described in Millán et al. (2005) (see disaggregation criteria in their Table 1). This method classifies each precipitation event on the basis of its characteristics and moisture source region, distinguishing between three categories (Fig. 1b, Table 4): (i) frontal systems associated with passing cold fronts from the west; (ii) convective-orographic storms driven by differential heating, sea breezes and local winds (Azorin-Molina et al., 2009); and (iii) easterly advection from the Mediterranean Sea (backdoor cold fronts). The Kruskal-Wallis $H$ test (sometimes also called the "one-way ANOVA on ranks") is a rank-based nonparametric test (Hammer et al., 2001) that was applied to the three rainfall categories to determine if there were statistically significant differences in their $\delta^{18} \mathrm{O}_{\mathrm{p}}$ distributions (Table 5). 
Table 4. Relative frequency (in \%) of the three rainfall types at every studied station.

\begin{tabular}{|c|c|c|c|c|c|c|c|}
\hline & \multicolumn{2}{|c|}{ Cantabrian coast } & \multicolumn{2}{|c|}{ Iberian Range } & \multirow{2}{*}{$\begin{array}{l}\text { Pyrenees } \\
\text { Borrastre }\end{array}$} & \multicolumn{2}{|c|}{ Mediterranean } \\
\hline & Oviedo & El Pindal & $\begin{array}{r}\text { Ortigosa } \\
\text { de Cameros }\end{array}$ & Molinos & & Barcelona & Mallorca \\
\hline Atlantic fronts & 68.09 & 71.29 & 58.7 & 51.8 & 65.2 & 58.49 & 40.82 \\
\hline Backdoor cold fronts & 14.89 & 16.83 & 20.6 & 23.9 & 11.8 & 24.53 & 38.78 \\
\hline Convective & 17.02 & 11.88 & 20.6 & 24.3 & 23.0 & 16.98 & 20.41 \\
\hline
\end{tabular}

Table 5. Kruskal-Wallis test performed on $\delta^{18} \mathrm{O}_{\mathrm{p}}$ data to determine if the three synoptic patterns are statistically different in terms of their isotopic composition. High values of the test (Kruskal-Wallis $H$ ) and low $p$ values indicate that at least two of the three synoptic patterns are statistically different in terms of $\delta^{18} \mathrm{O}_{\mathrm{p}}$ data.

\begin{tabular}{lrr|rrrrrr}
\hline & \multicolumn{2}{c}{ Cantabrian coast } & \multicolumn{2}{c}{ Iberian Range } & & Pyrenees & \multicolumn{2}{c}{ Mediterranean } \\
\cline { 2 - 4 } & Oviedo & El Pindal & $\begin{array}{c}\text { Ortigosa } \\
\text { de Cameros }\end{array}$ & Molinos & Borrastre & Barcelona & Mallorca \\
\hline Kruskal-Wallis $H$ & 3.017 & 10.86 & 23.3 & 48.38 & 47.84 & 4.109 & 22.23 \\
$p$ value & 0.221 & 0.004 & $8.7 \times 10^{-06}$ & $3.12 \times 10^{-11}$ & $4.09 \times 10^{-11}$ & 0.1282 & $1.49 \times 10^{-05}$ \\
\hline
\end{tabular}

\section{Results and discussion}

This section is focused on characterizing $\delta^{18} \mathrm{O}_{\mathrm{p}}$ in the studied transect in northern Spain on daily and monthly timescales and on analyzing the main factors behind the observed patterns. It is important to highlight here the high complexity of the hydrological cycle, with many processes playing a role in the formation of the isotope signals in precipitation. These range from source processes and transport processes to cloud and rainfall formation at the sampling site. Those factors may also overlap, making it difficult to disentangle their effects. The following sections are presented as follows: Sect. 4.1 and 4.2 are dedicated to daily and monthly data, respectively. Section 4.3 is dedicated to the influence of geographical parameters, such as distance from the coast or elevation of the studied sites. Section 4.4 deals with the role of meteorological parameters, in particular local air temperature and precipitation amount. Section 4.5 investigates the role of moisture origin in $\delta^{18} \mathrm{O}_{\mathrm{p}}$ variability, while Sect. 4.6 explores the role of rainfall type (convective, frontal) in determining $\delta^{18} \mathrm{O}_{\mathrm{p}}$.

\subsection{Daily rainfall isotopic variability}

The rainfall samples for the studied stations on a daily scale define local meteoric water lines (LMWLs) that are roughly parallel for all sites with a similar offset from the Global Meteoric Water Line (GMWL, $\delta^{2} \mathrm{H}=8 \cdot \delta^{18} \mathrm{O}+10$ ) (Fig. 2). All the slopes and the intercepts are lower than the GMWL, with slopes ranging from 6.9 to 7.2 and intercepts from 1.05 to 6.4 (Fig. 2). Thus, the LMWLs determined from daily data for each of the studied sites reveal a broadly similar regional signal and are consistent with previous studies using GNIP data from southern France (Genty et al., 2014), even though that study is based on monthly $\delta^{18} \mathrm{O}_{\mathrm{p}}$ data. The slopes obtained in our study are slightly lower compared to a previous analysis in the IP (Araguás-Araguás and Diaz Teijeiro, 2005), in which the sampling period only covered the rainy season (October to March).

Despite the differential time coverage of samples among the studied stations, the different daily time series of $\delta^{18} \mathrm{O}_{\mathrm{p}}$ at all stations are presented together (Fig. 3). Figures with $\delta^{18} \mathrm{O}_{p}, d$-excess and total precipitation for every separate site are included in the Supplement (Figs. S2 to S8). From 2010 to 2017 , daily $\delta^{18} \mathrm{O}_{\mathrm{p}}$ values are clearly lower in winter and higher (sometimes positive) in summer at all stations (Fig. 3). Yet some summer rainy episodes (e.g., the 25 June 2014 event in Borrastre and the 18 June 2016 one in Barcelona) exhibit values typical of winter after several days of rain or after an intense rainfall event $(41.6 \mathrm{~mm}$ in Borrastre from 23 to 25 June; $17.8 \mathrm{~mm}$ in Barcelona from 17 to 18 June). Also evident in Fig. 3 is the synchronicity among stations for specific events. A good example is the episode of 16-18 November 2013 (inset in Fig. 3) when very negative values were reached at Molinos (black line), Borrastre (green line) and Mallorca (red line). This period was characterized by intense widespread rain - e.g., $43 \mathrm{~mm}$ in Mallorca and $36 \mathrm{~mm}$ in Molinos (Table S1). At the three sites, this period was among the rainiest in our record with some of the lowest $\delta^{18} \mathrm{O}_{\mathrm{p}}$ values recorded.

It is evident from this large dataset that there is significant day-to-day variability, as large as the seasonal cycle, thus emphasizing the need for high-resolution measurements such as the ones presented in this study to characterize rainfall isotopic variability in northern Iberia. 

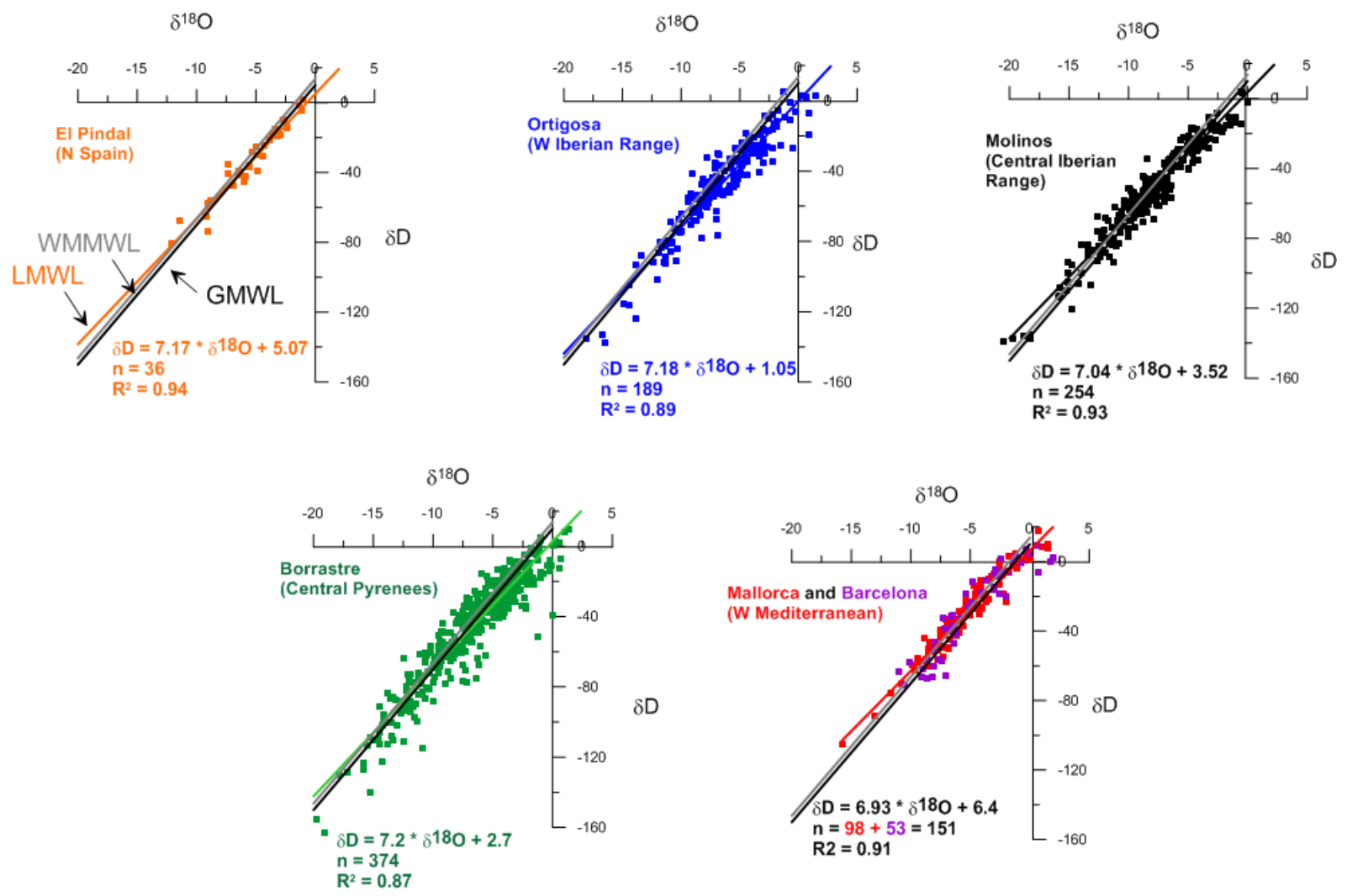

Figure 2. Scatter plots of $\delta^{2} \mathrm{H}_{\mathrm{p}}$ versus $\delta^{18} \mathrm{O}_{\mathrm{p}}$ in precipitation and local meteoric water lines (LMWLs), including equations, for El Pindal, Ortigosa de Cameros, Borrastre, Molinos and Mallorca-Barcelona stations. Note that the El Pindal plot includes only 36 samples since $\delta^{2} \mathrm{H}$ was not measured in the remaining samples. The difference in the other graphs in sample number $(n)$ with respect to those indicated in Table S1 is due to the removal of some samples that have been subject to evaporation effects (see text for more information). The Global Meteoric Water Line (GMWL) and western Mediterranean meteoric water line (WMMWL) are plotted in black and gray, respectively, in every graph.

\subsection{Monthly rainfall isotopic variability}

Seasonality in $\delta^{18} \mathrm{O}_{\mathrm{p}}$ in northern Iberia is further explored in Fig. 4 (data in Tables 2, S2). All stations exhibit a clear seasonal pattern in air temperature, with a peak in July-August and minimum values in December-January, and a similar seasonal signal in $\delta^{18} \mathrm{O}_{\mathrm{p}}$ with peak $\delta^{18} \mathrm{O}_{\mathrm{p}}$ values in summer and minimum $\delta^{18} \mathrm{O}_{\mathrm{p}}$ in winter. It is worth noting that precipitation exhibits a bimodal pattern with peaks in spring and autumn, which is not reflected in $\delta^{18} \mathrm{O}_{\mathrm{p}}$. The average seasonal differences between the $\delta^{18} \mathrm{O}_{\mathrm{p}}$ maximum values in July-August and minimum values in January-February are large: $5.8 \%$ at Borrastre, $4.6 \%$ at Ortigosa de Cameros, $6.2 \% o$ at Molinos and about $4 \%$ at Mallorca-Barcelona. Interestingly, the Oviedo-El Pindal samples reveal a very different pattern, with a marked reduction in seasonality compared to the other sites $\left(2 \% o \delta^{18} \mathrm{O}_{\mathrm{p}}\right.$ difference between winter and summer) (Fig. 4b). The seasonal difference from winter to summer in Oviedo-El Pindal is similar to the values published by Genty et al. (2014) for stations in southern France (e.g., $2.1 \%$ in Villars with only Atlantic influence; $3.6 \%$ in Orgnac with Atlantic and Mediterranean influence). The weak seasonality in the Oviedo-El Pindal $\delta^{18} \mathrm{O}_{\mathrm{p}}$ signal and the similarity to the Villars station could be related to the origin and type of precipitation (Sect. 4.5 and 4.6). Even though there are fewer precipitation events associated with fronts in summer than in winter, the Oviedo and Villars stations are characterized by a relatively constant source of precipitation throughout the year associated with Atlantic fronts and the absence of a dry season (Fig. 4a). This is in clear contrast to the other stations, which are characterized by a more hybrid Atlantic-Mediterranean climate (e.g., Orgnac; Genty et al., 2014). In particular, in Barcelona and Mallorca the seasonal difference in $\delta^{18} \mathrm{O}_{\mathrm{p}}$ monthly values is high (6\%o) (Fig. 4b). At these two stations, the influence of different air mass histories may be important to explain the observed high variability. These influences are further evaluated using backtrajectory and moisture uptake analysis in Sect. 4.5. 


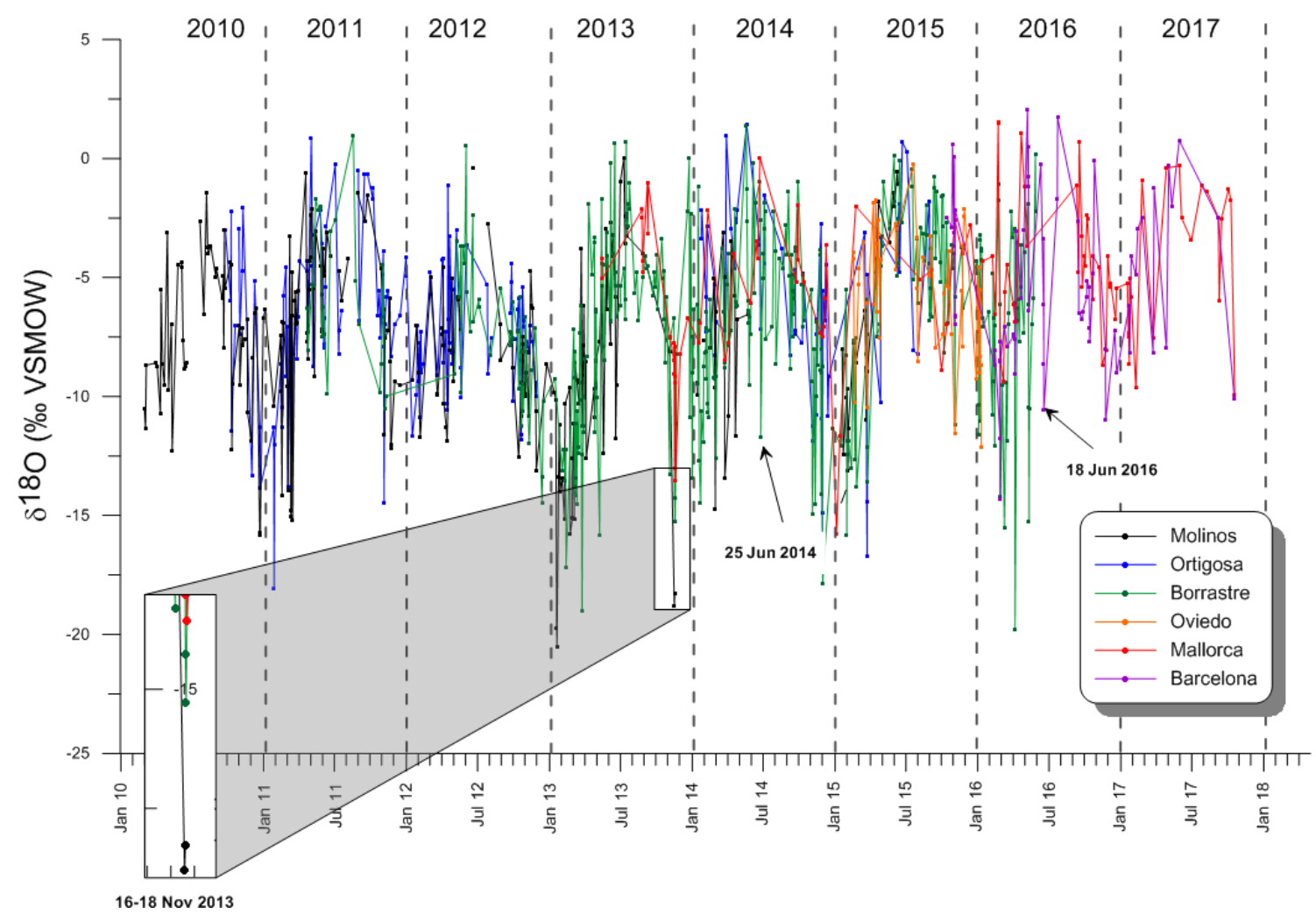

Figure 3. $\delta^{18} \mathrm{O}_{\mathrm{p}}$ daily time series for the studied stations presented versus time (2010-2017). Note that El Pindal samples (2006-2009) are not represented since they do not overlap with the time period of the other stations. See text for more explanation.

\subsection{Geographical controls on rainfall isotopic variability}

The combination of the various isotope effects results in consistent and spatially coherent variations in $\delta^{18} \mathrm{O}_{\mathrm{p}}$ values that are primarily related to geographical location and regional orography (Rozanski et al., 1993; Bowen, 2008), which are parameters that influence the circulation and therefore the air mass history. Preliminary observation of the monthly averaged $\delta^{18} \mathrm{O}_{\mathrm{p}}$ data (Table 2 and Fig. $4 \mathrm{~b}$ ) reveals similar values among the sites located at opposite ends of the transect: Oviedo and El Pindal compared to Barcelona and Mallorca. This similarity was unexpected since differences in moisture source conditions at the location of the moisture uptake were anticipated to be markedly different (see also Sect. 4.5). However, this similarity may be explained by two processes partly associated with the geographical location of the studied sites.

First, the fact that Oviedo and El Pindal rainfall samples show enriched $\delta^{18} \mathrm{O}_{\mathrm{p}}$ values is consistent with their location on the Cantabrian coast very close to the Atlantic Ocean, with climatological oceanic conditions characterized by relatively mild temperatures (Table 1). Thus, Oviedo and El Pindal are the stations that receive the first precipitation produced via contact with the Atlantic; they are the stations in the transect least affected by the "continental effect", which occurs when moist air and clouds move inland from the Atlantic Ocean and become gradually isotopically depleted due to progressive rainout (Dansgaard, 1964). Therefore, as we follow the typical displacement of an Atlantic front on its way to the IP from west to east, we find progressively more negative winter $\delta^{18} \mathrm{O}_{\mathrm{p}}$ values (see values for JanuaryFebruary-March in Table 2) going from El Pindal (-6.0\%), to Ortigosa de Cameros $(-8.1 \%$ ) to Borrastre $(-9.8 \%$ ) and, finally, to Molinos $(-10.0 \%$ ). This pattern is not as evident in other seasons when the entrance of Atlantic fronts is not the dominant synoptic situation that generates rainfall in the transect (Rüdisühli et al., 2020). In addition to this continental effect, which accounts for only a small gradient in $\delta^{18} \mathrm{O}_{\mathrm{p}}$ (about $0.002 \% \mathrm{~km}^{-1}$ in Europe as described in Rozanski et al., 1993), the higher annual mean air temperature in both Mallorca and Barcelona as well as Oviedo and El Pindal compared to the other stations (Table 1), may help explain their similar $\delta^{18} \mathrm{O}_{\mathrm{p}}$ values. The effect of warmer temperature on the less negative $\delta^{18} \mathrm{O}_{\mathrm{p}}$ values recorded will be discussed in more detail below (Sect. 4.4).

Second, another geographical factor that could account for the similarities found for stations at opposed ends of the transect is related to the elevation at those sites. The Ortigosa de Cameros, Molinos and Borrastre stations, the three stations located at a higher elevation, show monthly $\delta^{18} \mathrm{O}_{\mathrm{p}}$ values 


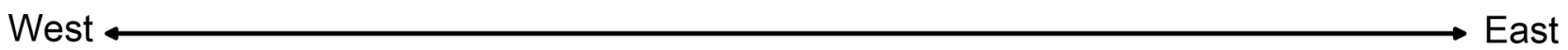

(a)
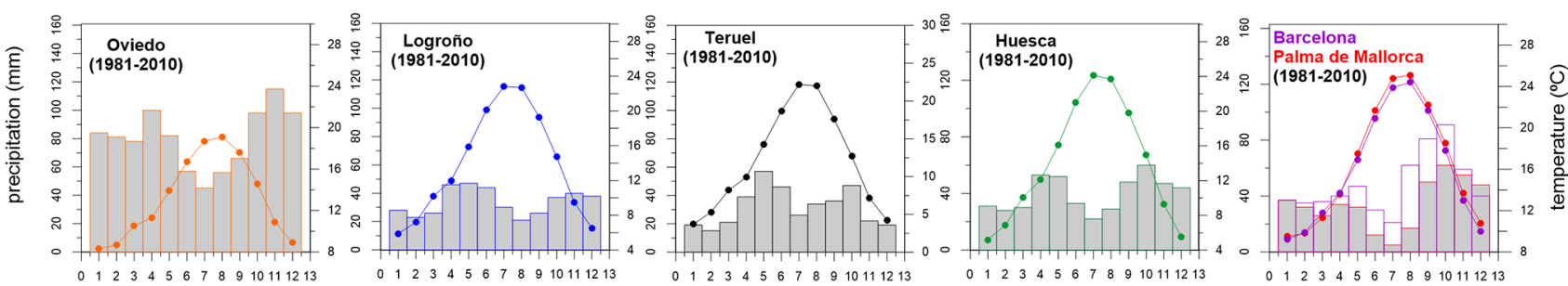

(b)
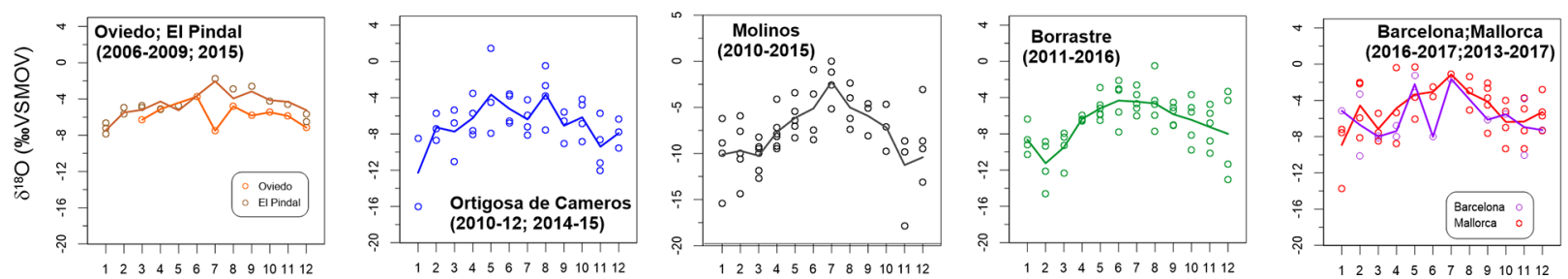

Figure 4. (a) Climographs showing monthly mean temperature (line with dots) and monthly mean rainfall (bars) obtained for the longest AEMET meteorological station records available next to the study sites (Oviedo, Logroño, Teruel, Huesca, Barcelona and Palma de Mallorca). Note that these stations are not at the same elevation or microclimate as the ones where rainfall was collected. For this reason, the climographs are indicated here to account for broad regional climates, while the correlations (Table 3) with meteorological data were performed using more proximal (although shorter in the recorded time interval) stations. (b) Variability of monthly weighted $\delta^{18} \mathrm{O}_{\mathrm{p}}$ at the studied sites. Dots represent monthly precipitation-amount-weighted averages, and lines are the mean of these monthly precipitation-amountweighted averages (see also Tables 2 and S2).

that are quite similar and, normally, more negative than the Oviedo, El Pindal, Barcelona and Mallorca sites, which are close to sea level. This pattern is particularly clear for autumn values (see monthly averaged $\delta^{18} \mathrm{O}_{\mathrm{p}}$ values from September to December in Table 2 along the west-to-east transect). Therefore, the "elevation effect" (Siegenthaler and Oeschger, 1980) likely also plays a role in explaining the similarities among coastal sites. Considering the $\delta^{18} \mathrm{O}_{\mathrm{p}}$ annual averages (Table 2), there is a difference of $2.3 \%$ o between Molinos (1040 m a.s.1.) and Mallorca (90 m a.s.1.). Based on the difference in elevation, the vertical isotopic gradient observed is $-0.24 \%$ per $100 \mathrm{~m}$ of elevation. This result is consistent with previous studies in other mountain ranges such as the Alps, where an altitudinal gradient of $-0.2 \%$ to $-0.3 \%$ o per $100 \mathrm{~m}$ of elevation was observed (Ambach et al., 1968; Siegenthaler and Oeschger, 1980).

In the next sections we explore how the geographical factors reviewed in this section (distance to the coast or continental effect and elevation effect) exert a direct influence on the observed spatial distribution of rainfall $\delta^{18} \mathrm{O}_{\mathrm{p}}$ by their influence on other controlling factors: air temperature, rainfall amount, air mass origin and rainfall type.

\subsection{The influence of air temperature and rain amount on the spatial distribution of rainfall $\delta^{18} \mathrm{O}_{p}$ values}

Spearman's rank correlation analysis (Table 3) reveals that $\delta^{18} \mathrm{O}_{\mathrm{p}}$ does not correlate with air temperature or amount of precipitation in a similar way at each station, at neither daily nor monthly timescales, thus reinforcing the need to conduct calibrating studies on a local basis, particularly when conducting paleoclimatic reconstructions (Leng, 2006). Air temperature appears to be the variable better correlated with $\delta^{18} \mathrm{O}_{\mathrm{p}}$ across the west-to-east transect, with modest but statistically significant correlations (daily scale) at all sites (red numbers in Table 3a) except Oviedo and Barcelona, most likely due to the low number of daily samples $(n=39$ and $n=53$, respectively). The coefficient of correlation among $\delta^{18} \mathrm{O}_{\mathrm{p}}$ daily values and air temperature is highly variably from west to east: El Pindal $\left(r_{\mathrm{s}}=0.34 ; p=0.001\right)$, Ortigosa de Cameros $\left(r_{\mathrm{s}}=0.25 ; p=0.001\right)$, Molinos $\left(r_{\mathrm{s}}=0.42\right.$; $p<0.001)$, Borrastre $\left(r_{\mathrm{s}}=0.29 ; p<0.01\right)$ and Mallorca $\left(r_{\mathrm{s}}=0.35 ; p=0.001\right)$ (Table $\left.3 \mathrm{a}\right)$. Regarding monthly values, air temperature is significantly correlated with $\delta^{18} \mathrm{O}_{\mathrm{p}}$ values at eastern stations, with the highest coefficients associated with higher-altitude sites (e.g., in Molinos with $r_{\mathrm{s}}=0.76$ and $p<0.001$ and in Borrastre with $\mathrm{r}_{s}=0.61$ and $p<0.001$ ) (Table 3b).

The influence of rainfall amount on $\delta^{18} \mathrm{O}_{\mathrm{p}}$ is strong in tropical regions where deep convection is frequent, although it may also occur in the extratropics in summer (Bar-Matthews et al., 2003; Treble et al., 2005). Correlation among rainfall amount and $\delta^{18} \mathrm{O}_{\mathrm{p}}$ is negative, associated with raindrop evaporation during periods of sparse rain (Dansgaard, 1964; Risi et al., 2008) when the relative humidity is low and is thus not a purely equilibrium process. In the studied transect, at the daily scale, the strongest correlation is 
observed in Barcelona $\left(r_{\mathrm{s}}=-0.35 ; p=0.029\right)$ (Table 3a). There is also a significant correlation at the two sites of the Iberian Range $\left(r_{\mathrm{s}}=-0.32 ; p=1.05 \times 10^{-05}\right.$ in Ortigosa and $r_{\mathrm{s}}=-0.19 ; p=0.005$ in Molinos). Interestingly, the westernmost stations (El Pindal and Oviedo) do not show a significant $\delta^{18} \mathrm{O}_{\mathrm{p}}$-precipitation correlation on daily or monthly scales. This lack of a correlation at the Atlantic sites contrasts with a previous study carried out in northern Spain at a site also characterized by an Atlantic climate (Matienzo depression), where a significant $\delta^{18} \mathrm{O}_{\mathrm{p}}$-precipitation monthly correlation was found $(r=-0.51 ; p<0.01)$ (Smith et al., 2016). In our study, the $\delta^{18} \mathrm{O}_{\mathrm{p}}$-precipitation correlation at a monthly scale is only significant in Molinos in the Iberian Range $\left(r_{\mathrm{s}}=-0.4 ; p=0.018\right)$, while no correlation is observed at the other sites (Table $3 b$ ).

To further assess the relative role of temperature and rainfall amount effects, a multiple regression model for $\delta^{18} \mathrm{O}_{\mathrm{p}}$ was carried out for the seven studied sites (Table 3c). The dependence of $\delta^{18} \mathrm{O}_{\mathrm{p}}$ on air temperature has been extensively studied, yielding an average slope for midlatitude continental stations of $0.58 \%$ per ${ }^{\circ} \mathrm{C}$ (Rozanski et al., 1993). In our data that value is highly variable in time and space. The strongest air temperature- $\delta^{18} \mathrm{O}_{\mathrm{p}}$ relationship, based on daily data, is found at Borrastre $\left(0.4 \%\right.$ o per $\left.{ }^{\circ} \mathrm{C}\right)$, Molinos $(0.4 \%$ o per $\left.{ }^{\circ} \mathrm{C}\right)$ and Barcelona $\left(0.37 \%\right.$ o per $\left.{ }^{\circ} \mathrm{C}\right)$, while the weakest is at Oviedo-El Pindal $\left(0.2 \%\right.$ o per $\left.{ }^{\circ} \mathrm{C}\right)$. The other three stations, Ortigosa de Cameros $\left(0.25 \%\right.$ o per $\left.{ }^{\circ} \mathrm{C}\right)$ and Mallorca $\left(0.317 \%\right.$ o per $\left.{ }^{\circ} \mathrm{C}\right)$, show intermediate values. Compared to other areas, such as the Alps with temperature- $\delta^{18} \mathrm{O}_{\mathrm{p}}$ gradients of 0.5 to $0.7 \%$ o per ${ }^{\circ} \mathrm{C}$, the results presented above indicate that, although important, air temperature only explains part of the observed $\delta^{18} \mathrm{O}_{\mathrm{p}}$ variability and is therefore not the only control. Air temperature, together with amount of precipitation (Table 3c), accounts for less than $40 \%$ of the variability of $\delta^{18} \mathrm{O}_{\mathrm{p}}$ in the study transect. Since the origin of air masses producing rainfall and the type of rainfall (i.e., convective vs. frontal) are also spatially dependent in northern Iberia, these variables and their influence on the observed $\delta^{18} \mathrm{O}_{\mathrm{p}}$ variability are investigated in Sect. 4.5 and 4.6 below.

\subsection{The role of the source effect in modulating $\delta^{18} \mathrm{O}_{\mathrm{p}}$}

The source effect describes how air masses derived from different moisture sources have distinct $\delta^{18} \mathrm{O}_{\mathrm{p}}$ values (e.g., Friedman, 2002). The source effect results from varying air mass histories, different conditions of the moisture source (air temperature, relative humidity and wind speed) and regional differences in the $\delta^{18} \mathrm{O}$ of the surface ocean (LeGrande and Schmidt, 2006). In the case of the northern IP, it is necessary to consider the effect of both the Atlantic Ocean and Mediterranean Sea as important sources of atmospheric moisture (Gimeno et al., 2010). Typical present-day $\delta^{18} \mathrm{O}$ values of seawater (LeGrande and Schmidt, 2006) indicate slightly different values for the Atlantic Ocean and the Mediterranean Sea due to temperature and salinity dif- ferences. Source $\delta^{18} \mathrm{O}$ values range from 1 to $1.5 \%$ in the subtropical Atlantic to $2 \%$ in the Mediterranean (Schmidt et al., 1999). These differences in the source (about $0.5 \%$ o$1 \%$ o) are small, but they are further modulated by the air mass history, thus resulting in a change in the relative influence of moisture sources on $\delta^{18} \mathrm{O}_{\mathrm{p}}$ along the west-to-east transect.

To evaluate the role of air mass origin in determining $\delta^{18} \mathrm{O}_{\mathrm{p}}$ values at a daily scale in northern Iberia and the Balearic Islands, back trajectories were calculated for all the rainy days and subsequently averaged into wind rose diagrams, following the representation used in previous studies (Smith et al., 2016), for three stations along our northern Iberia transect: Oviedo and Mallorca, the two extreme locations, and Borrastre, located at an intermediate location, comprising a total of 519 events. This analysis reveals the dominance of western trajectories at the three studied sites considering a $24 \mathrm{~h}$ lifetime, with very few episodes associated with a different direction (Fig. 5; see also Fig. S1 for trajectories calculated over a $120 \mathrm{~h}$ lifetime). In fact, comparison with the analysis carried out over $24 \mathrm{~h}$ and over $120 \mathrm{~h}$ shows only few episodes with trajectories from the SW (e.g., Borrastre) or SE (e.g., Mallorca), and, interestingly, they all have different $\delta^{18} \mathrm{O}_{\mathrm{p}}$ values (see below).

Despite the three sites sharing a common dominant WNW direction of Atlantic air mass origin, they behave quite differently in terms of amount of rainfall and $\delta^{18} \mathrm{O}_{\mathrm{p}}$ values for every event. Oviedo (with a temperate oceanic climate $-\mathrm{Cfb}$, Table 1) presents a narrower range in both rainfall amount and $\delta^{18} \mathrm{O}_{\mathrm{p}}$ in comparison to the other two sites (clearly seen at $120 \mathrm{~h}$, Fig. S1), as shown by the negligible frequency of rainfall amounts above $32 \mathrm{~mm}$ (orange) and below $2 \mathrm{~mm}$ (purple), while "extreme" events are much more common at the Borrastre and Mallorca sites. Similarly, in Fig. 5b, where the isotopic values for the different trajectories are plotted, Oviedo appears to be the station with more uniform $\delta^{18} \mathrm{O}_{\mathrm{p}}$ values (between $-10 \%$ and $-2 \%$ ) compared to the other two stations. Thus, in Borrastre and Mallorca, $\delta^{18} \mathrm{O}_{\mathrm{p}}$ values between $-8 \%$ and $-12 \%$ (red - green - yellow - dark blue) are only present for northwestern trajectories, while less negative values ( $-6 \%$ to $2 \%$ ) appear in events with SW and SE directions (see also Fig. S1). These results confirm the homogeneity of the Atlantic sites in terms of $\delta^{18} \mathrm{O}_{\mathrm{p}}$ amplitude (Cantabrian coastal sites: Oviedo, El Pindal) compared to the intermediate (Iberian range and Pyrenean sites: Ortigosa de Cameros, Molinos and Borrastre) stations already described by monthly data in Fig. 4.

This study of the source origin indicates a low, almost negligible, presence of trajectories associated with Mediterranean air mass advections. However, it is well-known that, since meteorological processes connected to convection (e.g., orographic, dynamic and thermodynamic) can produce moisture uptake in less than 6h (Romero et al., 2000, 1997; Tudurí and Ramis, 1997), they will not be well-captured in back-trajectory analyses that are computed for the previous $24 \mathrm{~h}$ (and even less for $120 \mathrm{~h}$; Fig. S1). Therefore, it is im- 


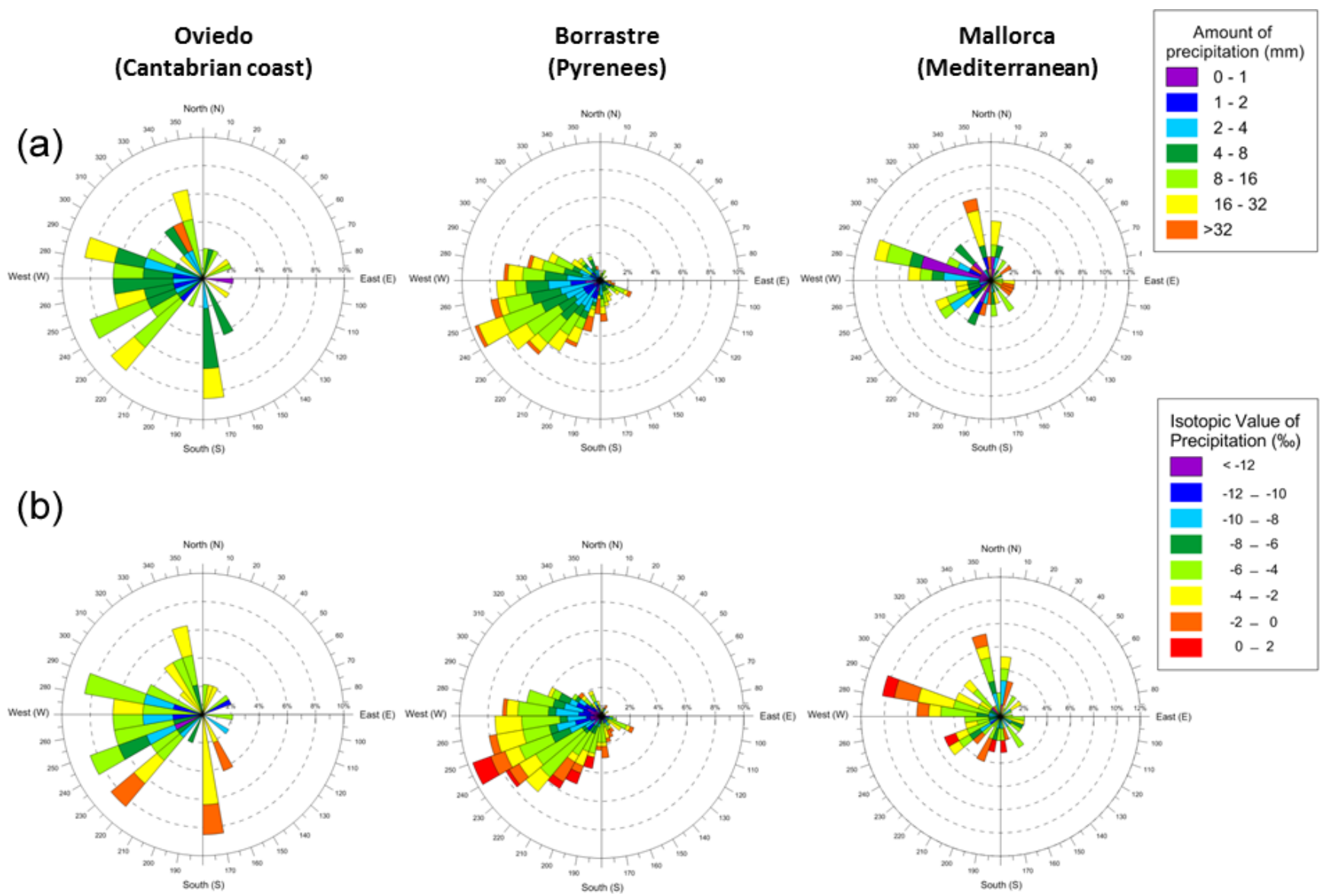

Figure 5. Wind roses showing the averaged back-trajectory directions over a $24 \mathrm{~h}$ lifetime for air masses that produced precipitation at three stations in northern Iberia: Oviedo (northern Spain), Borrastre (central Pyrenees) and Mallorca (Balearic Islands). (a) Amount of precipitation (measured at the nearest meteorological station) during the intervals of sample collection and (b) $\delta^{18} \mathrm{O}_{\mathrm{p}}$ indicated by colors (see legends). Source regions of each air mass, generated by averaging the direction of each point of the back trajectory (20 points), are divided into $10^{\circ}$ sectors. The percentages of back trajectories, whose averaged directions are associated with each $10^{\circ}$ sector, are shown as dashed circles (from $0 \%$ to $12 \%$ ).

portant to note that this method provides information on the air mass origin (source effect) but not on the moisture uptake regions. In that way, the dominant WNW air mass origin for the three studied stations is clear.

To account for the different moisture uptake processes along the studied trajectories, we followed the Baldini et al. (2010) methodology in a more restricted way (see Sect. 3.5) for the Oviedo-Borrastre-Mallorca stations (Fig. 6). Our findings highlight the importance of moisture uptake in generating the observed $\delta^{18} \mathrm{O}_{\mathrm{p}}$ differences along our west-to-east transect, with Oviedo and Mallorca showing a clearly dominant marine signal (Atlantic and Mediterranean, respectively), while in Borrastre the moisture uptake occurs over the whole Iberian Peninsula with the marine uptake being less important. The Oviedo station appears very homogenous in terms of the moisture uptake regions, clearly concentrated on the Portuguese margin and with very few events characterized by recycled continental moisture.
Interestingly, we observe seasonal differences in the dominant regions for moisture uptake, particularly at the Borrastre station. Thus, the contribution of continental moisture recycling, although observed along the whole year, is more frequent in summer, as deduced from the red dots located very close to the station, pointing to local convective processes (Fig. 6). The oceanic contribution to Borrastre rainfall is small and present mostly in winter (WNW oceanic source) and, to a lesser extent, spring and autumn (Mediterranean source). A recent study analyzing the trace element composition of precipitation also shows this seasonal tendency for the Pyrenees (Suess et al., 2019). This seasonality in the land vs. ocean moisture source contribution to Pyrenean precipitation is most certainly an important driver of the seasonal cycle of the isotope signals in precipitation, as was previously highlighted for many stations in Fig. 4b. The moisture uptake regions identified for Mallorca rainfall events are also quite heterogeneous, highlighting the Mediterranean as the domi- 


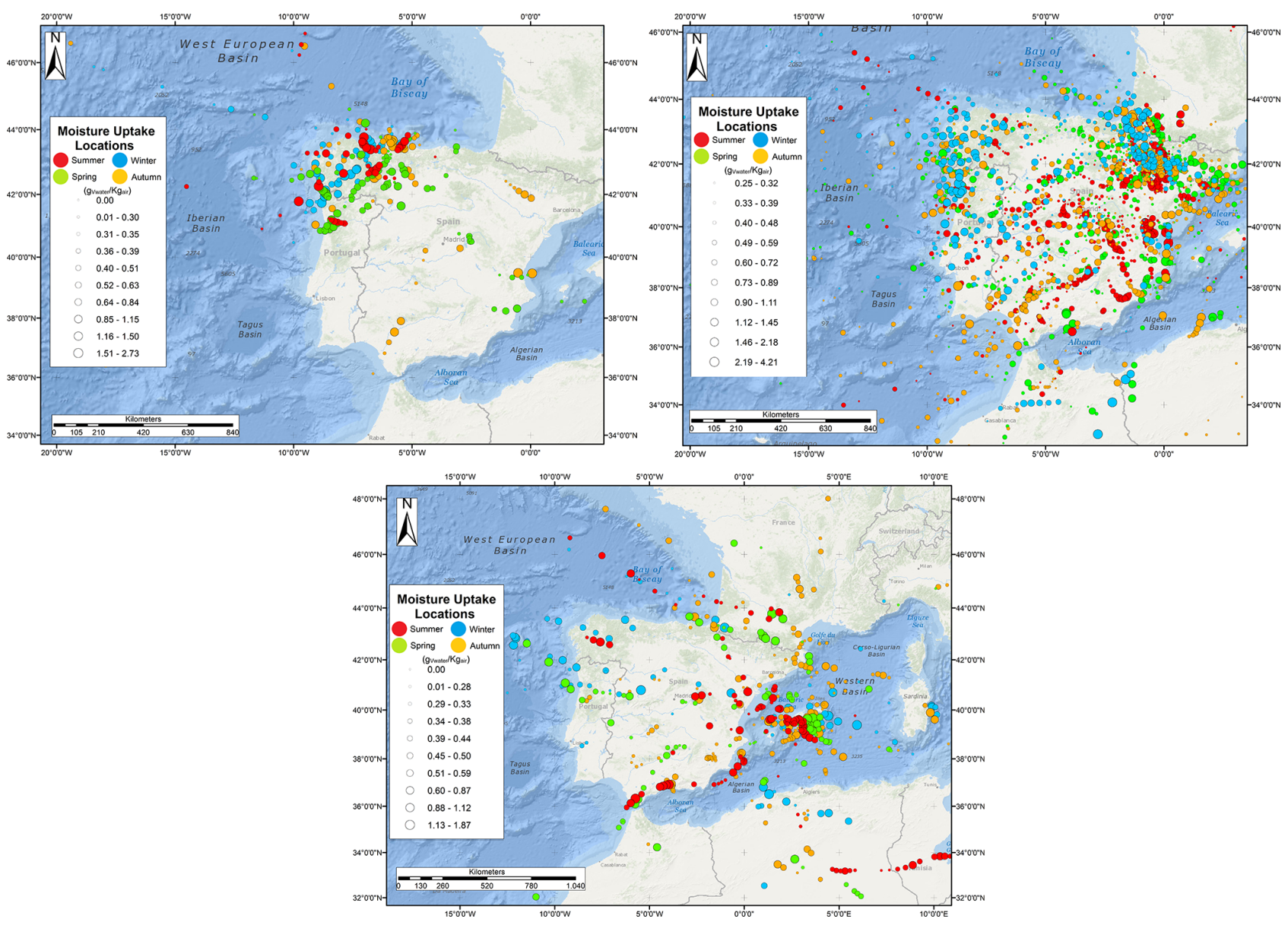

Figure 6. Maps of moisture uptake locations along rainfall backward trajectories represented for the Oviedo, Borrastre and Mallorca stations. See the legend for colors (indicating seasons) and dot sizes (indicating amount of moisture).

nant source for moisture uptake, while in winter-spring some events are observed to originate in the WNW sector. Additionally, some southern events arriving from North Africa are also detected, indicating the importance of that area to account for the Balearic Islands rainfall composition. In addition, we suggest that the Borrastre station offers a good representation of Iberian rainfall in terms of $\delta^{18} \mathrm{O}_{\mathrm{p}}$ composition since it receives moisture from a wide area, thus being of utility for further paleoclimatic studies in the Pyrenean region. Similarly, the Oviedo site appears to be a good prototype for the Atlantic region, allowing nearby paleoclimate sites to be compared with well-known marine cores from the Portuguese margin. Finally, the Mallorca site represents the western Mediterranean in terms of a preferred moisture uptake region.

\subsection{The influence of rainfall type on $\delta^{18} \mathrm{O}_{p}$ values}

The influence of rainfall type on $\delta^{18} \mathrm{O}_{\mathrm{p}}$ is well-documented globally, with different $\delta^{18} \mathrm{O}_{\mathrm{p}}$ observed depending on the type of precipitation: convective showers, frontal, continuous stratiform precipitation, etc. (Aggarwal et al., 2012).
This dependency is observed in previous studies on both daily and monthly timescales (Aggarwal et al., 2016), with a few examples of frontal precipitation (Aemisegger et al., 2015) and tropical convective processes (Risi et al., 2008) in Europe. These previous studies indicated that $\delta^{18} \mathrm{O}_{\mathrm{p}}$ values were lower when precipitation was dominantly stratiform and higher when it was mostly convective. The main reason explaining this difference involves the processes of condensation associated with boundary layer moisture, which produce higher isotope ratios in convective rain (Aggarwal et al., 2016). Additionally, some studies in the Mediterranean region also directly link the isotopic signature of precipitation to the prevailing weather conditions during the rainfall event (Celle-Jeanton et al., 2001), helping us to further understand the role of water vapor transport and the moisture cycling during convective events (Lee et al., 2019).

Here we explore how the specific synoptic situation, i.e., rainfall types and rainfall components, influences $\delta^{18} \mathrm{O}_{\mathrm{p}}$ values across the studied transect. Table 4 shows the percentage of rain events associated with each type of precipitation, which were previously defined following Millán et al. 
(2005) and are represented in Fig. 1b: (i) Atlantic frontal systems (westerly winds), (ii) convective-orographic storms and (iii) backdoor cold fronts from the Mediterranean Sea (easterly winds).

The prominence of rainfall associated with Atlantic fronts is evident (above $40 \%$ in the seven studied stations). This percentage decreases eastward from 68 and $71 \%$ in Oviedo and El Pindal, respectively, to 58 and $41 \%$ in Barcelona and Mallorca, respectively. A previous study at a northern Iberian site (Matienzo, Cantabria) indicates that approximately $80 \%$ of air masses originate in the North Atlantic and that their movement is associated with westerly frontal systems (Smith et al., 2016). This situation appears to be true for the Cantabrian coastal sites; for the Mediterranean and Iberian Range sites, however, the Atlantic and Mediterranean sources are of comparable importance (including backdoor cold fronts) (Table 4). Distance to the Mediterranean and elevation are also important factors in determining the frequency of rainfall associated with backdoor cold fronts. Thus, backdoor cold fronts are associated with $39 \%$ of Mallorca rain events and are still frequent situations at the two sites in the Iberian Range (21\% in Ortigosa de Cameros and $24 \%$ in Molinos). The frequency of convective precipitation is higher at the three mountain sites $(21 \%$ in Ortigosa de Cameros, $24 \%$ in Molinos and $23 \%$ in Borrastre) compared to the sites at lower elevation (17\% in Oviedo, $12 \%$ in $\mathrm{El}$ Pindal, $17 \%$ in Barcelona and $20 \%$ in Mallorca).

The Kruskal-Wallis test was applied to investigate if there were significant differences in the $\delta^{18} \mathrm{O}_{\mathrm{p}}$ values of the three rainfall types analyzed (Atlantic, backdoor frontal precipitation and convective) from the studied stations at the daily scale. Test values shown in Table 5 ( $p$ values $<0.05$ ) indicate that the $\delta^{18} \mathrm{O}_{\mathrm{p}}$ values of at least two of the three rainfall types are significantly different (this does not apply to Oviedo and Barcelona since the number of degrees of freedom is too small to yield a significant result). We conclude that the type of rainfall (frontal versus convective) is an important factor controlling $\delta^{18} \mathrm{O}_{\mathrm{p}}$ values in the studied transect at the daily scale. This result is also evident when the three rainfall types are represented according to their $\delta^{18} \mathrm{O}_{\mathrm{p}}$ composition (Fig. 7). Thus, regarding $\delta^{18} \mathrm{O}_{\mathrm{p}}$ composition, convective precipitation (in green in Fig. 7) is associated with the highest $\delta^{18} \mathrm{O}_{\mathrm{p}}$ values, while events related to Atlantic and backdoor cold fronts display more negative $\delta^{18} \mathrm{O}_{\mathrm{p}}$ values (albeit with a large spread), consistent with previous studies (Aggarwal et al., 2016). The highest $\delta^{18} \mathrm{O}_{\mathrm{p}}$ values associated with convective precipitation may be related to the critical role played by the re-evaporation of droplets, a process that usually takes place during convective rainfall (Bony et al., 2008). In any case, what is relevant here is the similarity between $\delta^{18} \mathrm{O}_{\mathrm{p}}$ values associated with the two types of frontal rains (Atlantic fronts and Mediterranean backdoor cold fronts), while there is a significant difference when considering the type of precipitation, i.e., convective versus frontal.
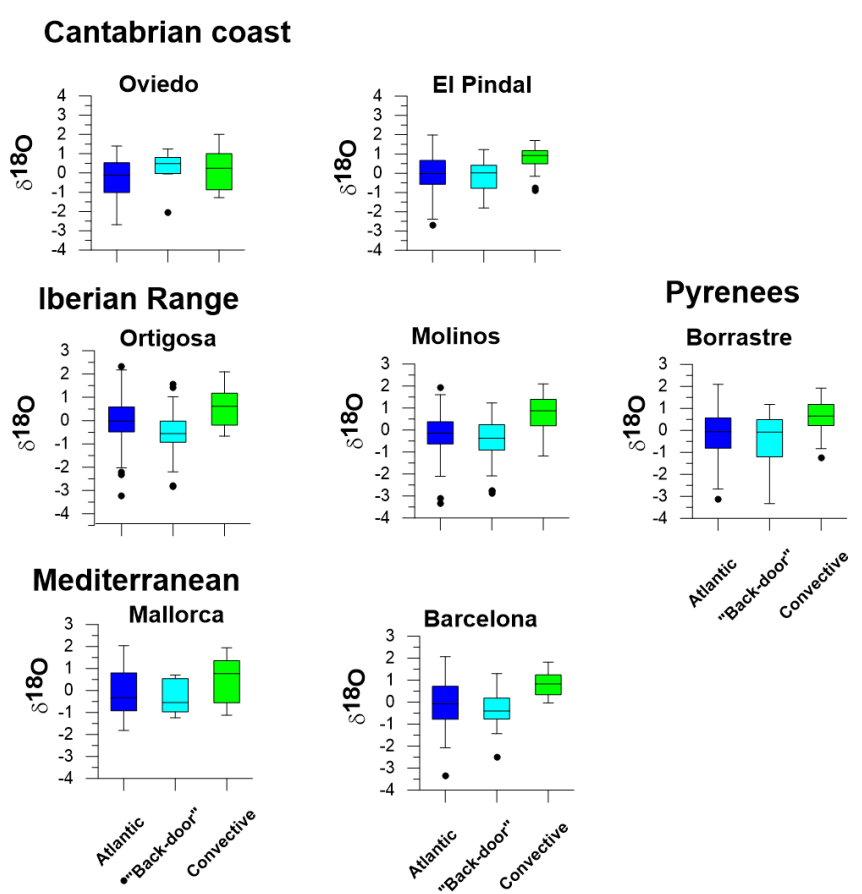

Figure 7. Box plots of $\delta^{18} \mathrm{O}_{\mathrm{p}}$ for the three identified rainfall types in northern Iberia: Atlantic fronts (in dark blue), backdoor cold fronts (light blue) and convective precipitation (in green) for the studied stations. The central rectangle spans the first quartile to the third quartile (the likely range of variation, or the IQR). A segment inside the rectangle shows the median, and "whiskers" above and below the box show the locations of the minimum and maximum. Values of $\delta^{18} \mathrm{O}_{\mathrm{p}}$ are normalized for better comparison among the seven stations. The Kruskal-Wallis test indicates that at least two of the three rainfall types are significantly different in terms of their $\delta^{18} \mathrm{O}_{\mathrm{p}}$ values.

\section{Conclusion}

The major findings in this study are summarized as follows.

- The analysis of $\delta^{18} \mathrm{O}_{\mathrm{p}}$ and $\delta^{2} \mathrm{H}_{\mathrm{p}}$ at seven stations along a west-to-east transect in northern Iberia and the Balearic Islands yields similar LMWLs, but all with lower slope and intercept values than the GMWL.

- Oviedo-El Pindal and Mallorca-Barcelona rainfall samples display the least negative $\delta^{18} \mathrm{O}_{\mathrm{p}}$ and $\delta^{2} \mathrm{H}_{\mathrm{p}}$ values in the transect. Our results suggest that this similarity between the two stations located at the western and eastern ends of the northern IP is due, firstly, to the initial condensate of water vapor generated over the North Atlantic and, secondly, to the influence of air masses originating in the Mediterranean Sea, together with the much warmer temperatures there than at the other three sites. Besides those effects, the "elevation effect" must be taken into account to explain the more negative average values at the three mid-transect stations (Ortigosa de Cameros, Borrastre and Molinos). 
- The seasonal variability is larger at Ortigosa de Cameros, Borrastre and Molinos, while it is reduced in Oviedo-El Pindal due to the single origin of rainfall in that area and the concentrated regions of moisture uptake along the Portuguese margin.

- Air temperature appears to be the best-correlated variable with $\delta^{18} \mathrm{O}_{\mathrm{p}}$ on daily and monthly timescales, with the highest air temperature- $\delta^{18} \mathrm{O}_{\mathrm{p}}$ dependency found at the Pyrenean station (slope of $0.38 \%$ per ${ }^{\circ} \mathrm{C}$ ). Only a few sites in the transect show a significant negative correlation with precipitation amount (monthly in Molinos; daily in Ortigosa de Cameros, Molinos, Barcelona and Mallorca).

- The dominance of rainfall with an Atlantic origin is clear in the study of rainfall back trajectories associated with each rainy event at the Oviedo, Borrastre and Mallorca sites, but the regions in which moisture uptake takes place are highly heterogeneous in space and time. At the Borrastre station, moisture comes from all over the Iberian Peninsula, with a dominance of recycled continental moisture and less influence of oceanic moisture in summer (Atlantic influence in winter, Mediterranean influence in spring and autumn).

- Convective rainfall yields higher $\delta^{18} \mathrm{O}_{\mathrm{p}}$ values, while rainfall events related to Atlantic and backdoor fronts exhibit more negative $\delta^{18} \mathrm{O}_{\mathrm{p}}$ values.

In conclusion, the northern Iberian region is under the influence of two climatic regimes (Atlantic and Mediterranean) and affected by different moisture source origins and uptake regions. Therefore, the synoptic-scale atmospheric circulation plays a key role in determining the ranges, values and seasonal distribution of $\delta^{18} \mathrm{O}_{\mathrm{p}}$ variability.

Data availability. All data are included in the Supplement Tables S1 and S2. Please see also https://doi.org/10.5281/zenodo.4806413 (Moreno, 2021).

Supplement. The supplement related to this article is available online at: https://doi.org/10.5194/acp-21-10159-2021-supplement.

Author contributions. The paper was conceived by AM, CPM, MB, CS, HS and IC. MI carried out the back-trajectory and moisture uptake studies, and CAM provided the synoptic patterns during rainfall days. JF, CO, ArM and ADH contributed to rainfall sampling and/or isotopic analyses. IB and FV helped with data interpretation. All authors contributed to the writing of the paper.

Competing interests. The authors declare that they have no conflict of interest.
Acknowledgements. We acknowledge the GA-LC-030/2011, CGL2010-16376 and CGL2009-10455/BTE projects. This work is a contribution of the Geomorfología y Cambio Global, Geotransfer and PaleoQ (IUCA) research groups (Aragón Government). We are extremely grateful to all people who carried out the rainfall sampling: Emilio Jordán (Molinos, Teruel), Ramiro Moreno (Borrastre, Huesca), María Ángeles Bonilla, Sara Sampedro, Juan Pérez (Ortigosa de Cameros, La Rioja), Montse Guart (Barcelona), Carmen González (Oviedo, Asturias), Alejandro Gallardo and Joan Fornós (Manacor, Mallorca). The Ebro Hydrographic Confederation network (SAIH, http://www.saihebro.com, last access: 20 June 2021) and the NOAA database are acknowledged for respectively providing meteorological data and software for the back-trajectory analyses (HYSPLIT). We thank Georgina Mateu of the University of Barcelona for the temperature and precipitation data. We also acknowledge the websites http://www.meteo4u.com, http://www.meteoclimatic.net (last access: 20 June 2021), http://www.larioja.org/emergencias-112/es/meteorologia (last access: 20 June 2021) and http://balearsmeteo.com (last access: 20 June 2021) as well as the Sant Llorenç des Cardassar observatory for the meteorological data in this region and the European Centre for Medium-Range Weather Forecasts for the ERA-Interim dataset. MB is supported by a postdoctoral fellowship (Juan de la Cierva - Formación program) provided by the Spanish Ministry of Science (ref. FJCI-2017-31725). IC and JF also thank the ICREA Academia and the Serra Húnter programs, respectively, from the Generalitat de Catalunya. We really appreciate the intense work by three reviewers, who helped us to improve the paper with their detailed comments and suggestions. We dedicate this study to our colleague Carlos Sancho, who intensively worked to produce this large $\delta^{18} \mathrm{O}$ rainfall dataset for northern Iberia, and to Ramiro Moreno, who collected rainfall samples and meteorological data in Borrastre village for 11 years. Both passed away, in February 2019 and April 2020, respectively.

Financial support. This research has been supported by the Agencia Estatal de Investigación (grant nos. CGL2016-77479-R, PID2019-106050RB-100, and CTM2013-48639-C2-2-R).

We acknowledge support for the publication fee by the CSIC Open-Access Publication Support Initiative through its Unit of Information Resources for Research (URICI).

Review statement. This paper was edited by Eliza Harris and reviewed by three anonymous referees.

\section{References}

AEMET and Instituto de Meteorologia de Portugal: Atlas climático Ibérico, Temperatura del aire y precipitación (1971-2000), Lisboa u.a., 2011.

Aemisegger, F., Spiegel, J. K., Pfahl, S., Sodemann, H., Eugster, W., and Wernli, H.: Isotope meteorology of cold front passages: A case study combining observations and modeling, Geophys. Res. Lett., 42, 5652-5660, https://doi.org/10.1002/2015GL063988, 2015. 
Aggarwal, P. K., Alduchov, O. A., Froehlich, K. O., AraguasAraguas, L. J., Sturchio, N. C., and Kurita, N.: Stable isotopes in global precipitation: A unified interpretation based on atmospheric moisture residence time, Geophys. Res. Lett., 39, L11705, https://doi.org/10.1029/2012GL051937, 2012.

Aggarwal, P. K., Romatschke, U., Araguas-Araguas, L., Belachew, D., Longstaffe, F. J., Berg, P., Schumacher, C., and Funk, A.: Proportions of convective and stratiform precipitation revealed in water isotope ratios, Nat. Geosci., 9, 624-629, https://doi.org/10.1038/ngeo2739, 2016.

Ambach, W., Dansgaard, W., Eisner, H., and Møller, J.: The altitude effect on the isotopic composition of precipitation and glacier ice in the Alps, Tellus, 20, 595-600, https://doi.org/10.3402/tellusa.v20i4.10040, 1968.

Araguás-Araguás, L. J. and Diaz Teijeiro, M. F.: Isotope composition of precipitation and water vapour in the Iberian Peninsula, in: Isotopic composition of precipitation in the Mediterranean Basin in relation to air circulation patterns and climate, Vienna, Austria, 173-191, 2005.

Archer, C. L. and Caldeira, K.: Historical trends in the jet streams, Geophys. Res. Lett., 35, L08803, https://doi.org/10.1029/2008GL033614, 2008.

Azorin-Molina, C., Connell, B. H., and Baena-Calatrava, R.: Sea-Breeze Convergence Zones from AVHRR over the Iberian Mediterranean Area and the Isle of Mallorca, Spain, J. Appl. Meteorol. Climatol., 48, 2069-2085, https://doi.org/10.1175/2009JAMC2141.1, 2009.

Azorin-Molina, C., Chen, D., Tijm, S., and Baldi, M.: A multi-year study of sea breezes in a Mediterranean coastal site: Alicante (Spain), Int. J. Climatol., 31, 468-486, https://doi.org/10.1002/joc.2064, 2011.

Baldini, L. M., McDermott, F., Baldini, J. U. L., Fischer, M. J., and Möllhoff, M.: An investigation of the controls on Irish precipitation $\delta^{18} \mathrm{O}$ values on monthly and event timescales, Clim. Dynam., 35, 977-993, https://doi.org/10.1007/s00382-010-0774-6, 2010.

Bar-Matthews, M., Ayalon, A., Gilmour, M. A., Matthews, A., and Hawkesworth, C. J.: Sea-land oxygen isotopic relationships from planktonic foraminifera and speleothems in the Eastern Mediterranean region and their implication for paleorainfall during interglacial intervals, Geochim. Cosmochim. Ac., 67, 3181-3199, 2003.

Bartolomé, M., Moreno, A., Sancho, C., Stoll, H. M., Cacho, I., Spötl, C., Belmonte, Á., Edwards, R. L., Cheng, H., and Hellstrom, J. C.: Hydrological change in Southern Europe responding to increasing North Atlantic overturning during Greenland Stadial 1, P. Natl. Acad. Sci. USA, 112, 6568-6572, https://doi.org/10.1073/pnas.1503990112, 2015.

Berrisford, P., Dee, D. P., Fielding, M., Fuentes, M., Kallberg, P. W., Kobayashi, S., and Uppala, S.: The ERA-Interim archive, ECMWF, ERA report series, 20 pp., 2009.

Bony, S., Risi, C., and Vimeux, F.: Influence of convective processes on the isotopic composition $\left(\delta^{18} \mathrm{O}\right.$ and $\delta \mathrm{D})$ of precipitation and water vapor in the tropics: 1 . Radiative-convective equilibrium and Tropical Ocean-Global Atmosphere-Coupled Ocean-Atmosphere Response Experiment (TOGA-COARE) simulations, J. Geophys. Res.-Atmos., 113, D19305, https://doi.org/10.1029/2008JD009942, 2008.
Bowen, G. J.: Spatial analysis of the intra-annual variation of precipitation isotope ratios and its climatological corollaries, J. Geophys. Res., 113, D05113, https://doi.org/10.1029/2007JD009295, 2008.

Coleman, M. L., Shepherd, T. J., Durham, J. J., Rouse, J. E., and Moore, G. R.: Reduction of water with zinc for hydrogen isotope analysis, Anal. Chem., 54, 993-995, https://doi.org/10.1021/ac00243a035, 1982.

Craig, H.: Isotopic Variations in Meteoric Waters, Science, 133, 1702-1703, https://doi.org/10.1126/science.133.3465.1702, 1961.

Dansgaard, W.: Stable isotopes in precipitation, Tellus, 16, 436468, https://doi.org/10.1111/j.2153-3490.1964.tb00181.x, 1964.

Dee, D. P., Uppala, S. M., Simmons, A. J., Berrisford, P., Poli, P., Kobayashi, S., Andrae, U., Balmaseda, M. A., Balsamo, G., Bauer, P., Bechtold, P., Beljaars, A. C. M., Berg, L. van de, Bidlot, J., Bormann, N., Delsol, C., Dragani, R., Fuentes, M., Geer, A. J., Haimberger, L., Healy, S. B., Hersbach, H., Hólm, E. V., Isaksen, L., Kållberg, P., Köhler, M., Matricardi, M., McNally, A. P., Monge-Sanz, B. M., Morcrette, J.-J., Park, B.-K., Peubey, C., Rosnay, P. de, Tavolato, C., Thépaut, J.-N., and Vitart, F.: The ERA-Interim reanalysis: configuration and performance of the data assimilation system, ERA Report, 137, 553597, https://doi.org/10.1002/qj.828, 2011.

Díaz-Tejeiro, M. F., Rodríguez, J., Pérez, E., Castaño, S., and Araguás, L.: Factors controlling the stable isotopic composition of recent precipitation in Spain, in: Advances in Isotope Hydrology and its Role in Sustainable Water Resources Management (IHS-2007), Proceedings Series. Proceedings of an International Symposium on Advances in Isotope Hydrology and its Role in Sustainable Water Resources Management (IHS-2007), 239-249, 2007.

Díaz-Tejeiro, M. F., Pérez-Zabaleta, E., Prado-Pérez, A., Bardasano-Picazo, L., Muñoz-Delavarga, D., and Rodríguez, J.: La Red Española de Vigilancia de Isótopos en la Precipitación (REVIP), XI CONGRESO NACIONAL DE GEOQUÍMICA, Soria, 2013.

Domínguez-Villar, D., Wang, X., Krklec, K., Cheng, H., and Edwards, R. L.: The control of the tropical North Atlantic on Holocene millennial climate oscillations, 45, 303-306, https://doi.org/10.1130/G38573.1, 2017.

Draxler, R. R. and Rolph, G. D.: HYSPLIT (HYbrid SingleParticle Lagrangian Integrated Trajectory) Model access via NOAA ARL READY Website, available at: https://www.ready. noaa.gov/HYSPLIT.php (last access: 20 June 2021), 2010.

Epstein, S. and Mayeda, T.: Variation of $\mathrm{O}^{18}$ content of waters from natural sources, Geochim. Cosmochim. Ac., 4, 213-224, https://doi.org/10.1016/0016-7037(53)90051-9, 1953.

Field, R. D.: Observed and modeled controls on precipitation $\delta^{18} \mathrm{O}$ over Europe: From local temperature to the Northern Annular Mode, J. Geophys. Res., 115, D12101, https://doi.org/10.1029/2009JD013370, 2010.

Fischer, B. M. C., Aemisegger, F., Graf, P., Sodemann, H., and Seibert, J.: Assessing the Sampling Quality of a Low-Tech Low-Budget Volume-Based Rainfall Sampler for Stable Isotope Analysis, Front. Earth Sci., 7, 244, https://doi.org/10.3389/feart.2019.00244, 2019.

Fischer, M. and Baldini, L.: A climate-isotope regression model with seasonally-varying and time-integrated relationships, Clim. 
Dynam., 37, 2235-2251, https://doi.org/10.1007/s00382-0111009-1, 2011.

Friedman, I.: Stable isotope composition of waters in the Great Basin, United States 1. Air-mass trajectories, J. Geophys. Res., 107, 4400, https://doi.org/10.1029/2001JD000565, 2002.

Genty, D., Labuhn, I., Hoffmann, G., Danis, P. A., Mestre, O., Bourges, F., Wainer, K., Massault, M., Van Exter, S., Régnier, E., Orengo, P., Falourd, S., and Minster, B.: Rainfall and cave water isotopic relationships in two SouthFrance sites, Geochim. Cosmochim. Ac., 131, 323-343, https://doi.org/10.1016/j.gca.2014.01.043, 2014.

Gimeno, L., Nieto, R., Trigo, R. M., Vicente-Serrano, S. M., and Lopez-Moreno, J. I.: Where does the Iberian Peninsula moisture come from? An answer based on a Lagrangian approach, J. Hydrometeorol., 11, 421-436, 2010.

Hammer, O., Harper, D. A. T., and Ryan, P. D.: PAST: Paleontological statistics software package for education and data analysis, Palaeontol. Electron., 4, 9 pp., 2001.

Iglesias González, M. I.: Variabilidad climática del noroeste de la península ibérica durante los últimos 1500 años, descrita por espeleotemas de diversas cuevas del principado de Asturias, Universidad de Oviedo, available at: http://purl.org/dc/dcmitype/ Text (last access: 20 June 2021), 2019.

Jeelani, G., Deshpande, R. D., Galkowski, M., and Rozanski, K.: Isotopic composition of daily precipitation along the southern foothills of the Himalayas: impact of marine and continental sources of atmospheric moisture, Atmos. Chem. Phys., 18, 87898805, https://doi.org/10.5194/acp-18-8789-2018, 2018.

Kawale, J., Chatterjee, S., Kumar, A., Liess, S., Steinbach, M., and Kumar, V.: Anomaly construction in climate data: issues and challenges, Mountain View, California, USA, 189-203, 2011.

Krklec, K. and Domínguez-Villar, D.: Quantification of the impact of moisture source regions on the oxygen isotope composition of precipitation over Eagle Cave, central Spain, https://doi.org/10.1016/j.gca.2014.03.011, 2014.

Lachniet, M. S.: Climatic and environmental controls on speleothem oxygen-isotope values, Quaternary Sci. Rev., 28, 412-432, 2009.

Lee, K.-O., Aemisegger, F., Pfahl, S., Flamant, C., Lacour, J.-L., and Chaboureau, J.-P.: Contrasting stable water isotope signals from convective and large-scale precipitation phases of a heavy precipitation event in southern Italy during HyMeX IOP 13: a modelling perspective, Atmos. Chem. Phys., 19, 7487-7506, https://doi.org/10.5194/acp-19-7487-2019, 2019.

LeGrande, A. N. and Schmidt, G. A.: Global gridded data set of the oxygen isotopic composition in seawater, Geophys. Res. Lett., 33, L12604, https://doi.org/200610.1029/2006GL026011, 2006.

Leng, M. J.: Isotopes in palaeoenvironmental research, Springer, Dordrecht, 334 pp., 2006.

Llasat, M.-C., Martín, F., and Barrera, A.: From the concept of "Kaltlufttropfen" (cold air pool) to the cut-off low. The case of September 1971 in Spain as an example of their role in heavy rainfalls, Meteorol. Atmos. Phys., 96, 43-60, https://doi.org/10.1007/s00703-006-0220-9, 2007.

López-Blanco, C., Andrews, J., Dennis, P., Miracle, M. R., and Vicente, E.: Sedimentary response of lake El Tobar, Spain, to climate: lake level changes after the Maunder Minimum, J. Quaternary Sci., 31, 905-918, https://doi.org/10.1002/jqs.2915, 2016.
Martín-Vide, J. and Olcina Cantos, J.: Climas y tiempos de España, Alianza Editorial, Madrid, Springer, Dordrecht, 258 pp., 2001.

Millán, M. M., Estrela, M. J., and Miró, J.: Rainfall Components: Variability and Spatial Distribution in a Mediterranean Area (Valencia Region), J. Climate, 18, 2682-2705, https://doi.org/10.1175/JCLI3426.1, 2005.

Moreno, A.: Northern Iberian rainfall stable isotope values at event scale, Zenodo [data set], https://doi.org/10.5281/zenodo.4806413, 2021.

Moreno, A., Sancho, C., Bartolomé, M., Oliva-Urcia, B., DelgadoHuertas, A., Estrela, M. J., Corell, D., López-Moreno, J. I., and Cacho, I.: Climate controls on rainfall isotopes and their effects on cave drip water and speleothem growth: the case of Molinos cave (Teruel, NE Spain), Clim. Dynam., 43, 221-241, https://doi.org/10.1007/s00382-014-2140-6, 2014.

Moreno, A., Pérez-Mejías, C., Bartolomé, M., Sancho, C., Cacho, I., Stoll, H., Delgado-Huertas, A., Hellstrom, J., Edwards, R. L., and Cheng, H.: New speleothem data from Molinos and Ejulve caves reveal Holocene hydrological variability in northeast Iberia, Quaternary Res., 1-11, https://doi.org/10.1017/qua.2017.39, 2017.

Pérez-Mejías, C., Moreno, A., Sancho, C., Bartolomé, M., Stoll, H., Osácar, M. C., Cacho, I., and Delgado-Huertas, A.: Transference of isotopic signal from rainfall to dripwaters and farmed calcite in Mediterranean semi-arid karst, Geochim. Cosmochim. Ac., 243, 66-98, https://doi.org/10.1016/j.gca.2018.09.014, 2018.

Pérez-Mejías, C., Moreno, A., Sancho, C., Martín-García, R., Spötl, C., Cacho, I., Cheng, H., and Edwards, R. L.: Orbital-tomillennial scale climate variability during Marine Isotope Stages 5 to 3 in northeast Iberia, Quaternary Sci. Rev., 224, 105946, https://doi.org/10.1016/j.quascirev.2019.105946, 2019.

Risi, C., Bony, S., and Vimeux, F.: Influence of convective processes on the isotopic composition $\left(\delta^{18} \mathrm{O}\right.$ and $\left.\delta \mathrm{D}\right)$ of precipitation and water vapor in the tropics: 2 . Physical interpretation of the amount effect, J. Geophys. Res., 113, D19306, https://doi.org/10.1029/2008JD009943, 2008.

Romero, R., Ramis, C., and Alonso, S.: Numerical simulation of an extreme rainfall event in Catalonia: Role of orography and evaporation from the sea, 123, 537-559, https://doi.org/10.1002/qj.49712353902, 1997.

Romero, R., Doswell, C. A., and Ramis, C.: Mesoscale Numerical Study of Two Cases of Long-Lived QuasiStationary Convective Systems over Eastern Spain, Mon. Weather Rev., 128, 3731-3751, https://doi.org/10.1175/15200493(2001)129<3731:MNSOTC>2.0.CO;2, 2000.

Rozanski, K., Araguás-Araguás, L., and Gonfiantini, R.: Isotopic patterns in modern global precipitation, Geophys. Monogr. Ser., 78, 1-36, 1993.

Rüdisühli, S., Sprenger, M., Leutwyler, D., Schär, C., and Wernli, H.: Attribution of precipitation to cyclones and fronts over Europe in a kilometer-scale regional climate simulation, Weather Clim. Dynam., 1, 675-699, https://doi.org/10.5194/wcd-1-6752020, 2020.

Sancho, C., Arenas, C., Vázquez-Urbez, M., Pardo, G., Lozano, M. V., Peña-Monné, J. L., Hellstrom, J., Ortiz, J. E., Osácar, M. C., Auqué, L., and Torres, T.: Climatic implications of the Quaternary fluvial tufa record in the NE Iberian Peninsula over the last $500 \mathrm{ka}$, Quaternary Res., 84, 398-414, https://doi.org/10.1016/j.yqres.2015.08.003, 2015. 
Sancho, C., Belmonte, Á., Bartolomé, M., Moreno, A., Leunda, M., and López-Martínez, J.: Middle-to-late Holocene palaeoenvironmental reconstruction from the A294 ice-cave record (Central Pyrenees, northern Spain), Earth Planet. Sc. Lett., 484, 135-144, https://doi.org/10.1016/j.epsl.2017.12.027, 2018.

Schmidt, G. A., Bigg, G. R., and Rohling, E. J.: Global Seawater Oxygen-18 Database - v1.22, Global Seawater Oxygen-18 Database - v1.22, 1999.

Siegenthaler, U. and Oeschger, H.: Correlation of ${ }^{18} \mathrm{O}$ in precipitation with temperature and altitude, Nature, 285, 314-317, https://doi.org/10.1038/285314a0, 1980.

Smith, A., Wynn, P., Barker, P., Leng, M., Noble, S., and Stott, A.: Cave monitoring and the potential for palaeoclimate reconstruction from Cueva de Asiul, Cantabria (N. Spain), Int. J. Speleol., 45, 1-9, https://doi.org/10.5038/1827-806X.45.1.1928, 2016.

Stoll, H., Mendez-Vicente, A., Gonzalez-Lemos, S., Moreno, A., Cacho, I., Cheng, H., and Edwards, R. L.: Interpretation of orbital scale variability in mid-latitude speleothem $\delta^{18} \mathrm{O}$ : Significance of growth rate controlled kinetic fractionation effects, Quaternary Sci. Rev., 127, 215-228, https://doi.org/10.1016/j.quascirev.2015.08.025, 2015.
Suess, E., Aemisegger, F., Sonke, J. E., Sprenger, M., and Wernli, H.: Marine versus continental sources of iodine and selenium in rainfall at two European high-altitude locations, Environ. Sci. Technol., 53, 1905-1917, 2019.

Treble, P. C., Chappell, J., Gagan, M. K., McKeegan, K. D., and Harrison, T. M.: In situ measurement of seasonal $\delta^{18} \mathrm{O}$ variations and analysis of isotopic trends in a modern speleothem from southwest Australia, Earth Planet. Sc. Lett., 233, 17-32, https://doi.org/10.1016/j.epsl.2005.02.013, 2005.

Tudurí, E. and Ramis, C.: The Environments of Significant Convective Events in the Western Mediterranean, Weather Forecast., 12, 294-306, https://doi.org/10.1175/15200434(1997)012<0294:TEOSCE>2.0.CO;2, 1997.

Tyler, J. J., Jones, M., Arrowsmith, C., Allott, T., and Leng, M. J.: Spatial patterns in the oxygen isotope composition of daily rainfall in the British Isles, Clim. Dynam., 47, 1971-1987, https://doi.org/10.1007/s00382-015-2945-y, 2016. 